\title{
The relative importance of wind-driven and chimney effect cave ventilation: Observations in Postojna Cave (Slovenia)
}

\author{
Lovel Kukuljan (10) ${ }^{1}$, Franci Gabrovšek (1) $^{1 *}$, and Matthew D. Covington ([i] ${ }^{2}$ \\ ${ }^{1}$ Karst Research Institute ZRC SAZU, Titov trg 2, 6230 Postojna, Slovenia \\ ${ }^{2}$ Department of Geosciences, University of Arkansas, Fayetteville, AR 72701, Arkansas, USA
}

\begin{abstract}
Density-driven chimney effect airflow is the most common form of cave ventilation, allowing gas exchange between the outside and the karst subsurface. However, cave ventilation can also be driven by other mechanisms, such as barometric changes or pressure differences induced by the outside winds. We discuss the mechanism and dynamics of wind-driven ventilation using observations in Postojna Cave, Slovenia. We show how seasonal airflow patterns driven by the chimney effect are substantially modified by outside winds. Wind flow over irregular topography forms near-surface air pressure variations and thus pressure differences between cave entrances at different locations. These pressure differences depend on wind speed and direction and their relationship to surface topography and the location of cave entrances. Winds can act in the same or opposite direction as the chimney effect and can either enhance, diminish or even reverse the direction of the density-driven airflows. To examine the possibility of wind-driven flow, we used a computational fluid dynamics model to calculate the wind pressure field over Postojna Cave and the pressure differences between selected points for different configurations of wind speed and direction. We compared these values with those obtained from airflow measurements in the cave and from simple theoretical considerations. Despite the simplicity of the approach and the complexity of the cave system, the comparisons showed satisfactory agreement. This allowed a more general assessment of the relative importance of wind pressure for subsurface ventilation. We are certain that this example is not unique and that the wind-driven effect needs to be considered elsewhere to provide better insights into the dynamics of cave climate, air composition or dripwater geochemistry.
\end{abstract}

Keywords: $\quad$ cave airflow, pressure difference, driving mechanism, microclimate, Postojna Cave

Received 17 May 2021; Revised 4 August 2021; Accepted 18 August 2021

Citation: Kukuljan L., Gabrovšek F., Covington M.D., 2021. The relative importance of wind-driven and chimney effect cave ventilation: Observations in Postojna Cave (Slovenia). International Journal of Speleology, 50(3), 275-288. https://doi.org/10.5038/1827-806X.50.3.2392

\section{INTRODUCTION}

Advection is the main driver of spatial and temporal variations in atmospheric parameters in the karst vadose zone. Subsurface airflows are controlled by cave geometry, its connection with the surface, and variations in external weather and climate (Cigna, 1968; Badino, 2010; Borsato et al., 2015; James et al., 2015). In karst areas with temperate climates and adequate topographic variation, the most common driving force is the density difference between outside and cave air. The inside and outside air temperatures, and thus densities, often differ, resulting in pressure differences that drive airflow between entrances at different elevations. In the warm period, the internal air is heavier and the airflow is directed from higher to lower entrances. In the cold periods, the situation is reversed. The typical term for density- or buoyancy- driven airflow is the "chimney" or "stack effect" (Covington \& Perne, 2015). It is not uncommon to find density contrasts and corresponding compensating airflow also in caves with single entrances (Milanolo \& Gabrovšek, 2009; Smith et al., 2015, 2016).

Other sources of ventilation in caves are possible. Equilibration of cave atmosphere with the outside barometric variations results in compensating air currents, which are well observable in caves with large cavities and small connecting passages or entrances, (Conn, 1966; Fernandez-Cortes et al., 2009; Pflitsch et al., 2010; Smith et al., 2015). Outside wind flow over surface relief causes near-ground pressure variations and thus pressure differences and airflow between different entrances of cave systems. In this work we use terms wind-driven or wind induced airflow for such situations. The mechanisms of natural ventilation, both density- and wind-driven, are well known to 
architects and civil engineers (Allard \& Ghiaus, 2006; Yang \& Clements-Croome, 2012). However, winddriven or wind-induced ventilation in caves has only been explored in a handful of studies (Kowalczk \& Froelich, 2010; Fairchild \& Baker, 2012; Noronha et al., 2017; Riechelmann et al., 2019; Kašing \& Lenart, 2020; Mattey et al., 2021). In some environments, such a ventilation mechanism may dominate over the chimney effect. For example, in a single-entrance cave in a tropical environment, where seasonal airflows are not expected, Noronha et al. (2017) showed that trade winds cause a seasonal decrease in cave air $p \mathrm{CO}_{2}$ and a concomitant increase in calcite precipitation. One may wonder about the significance of such effects on cave climate, air composition, and carbonate chemistry for other caves and karst areas in general. An interesting study by Nachson et al (2012) demonstrates the role of ground-surface winds on fracture ventilation and stresses its significance in gas exchange at the Earthatmosphere interface.

In this study we investigate the influence of winds on the ventilation pattern of Postojna Cave, Slovenia, and compare the observations with theoretical estimates and estimates obtained from a topographic wind flow model. These results build on our previous findings of the strong influence of outside winds on the seasonal cave ventilation (Kukuljan et al., 2021). The procedures discussed here can be applied in any other karst area where there are sufficient winds and where the configuration of the cave and its entrances allow for detection of the wind-driven effect.

\section{THEORETICAL AIRFLOW DRIVING PRESSURES}

We can safely assume that the airflows measured in karst conduits are turbulent (Covington, 2016). In this case, the relationship between airflow velocity and pressure difference can be approximated by one of the empirical relations for turbulent flow in a pipe such as the Darcy-Weisbach Equation, which yields a square-root relationship between the airflow velocity and the driving pressure $v \propto \sqrt{\Delta p}$. In the simplest scenario of a cave with two entrances with a relative height difference of $\Delta h$, an outside temperature of $T_{\text {out }}$ and a cave air temperature of $T_{i n}$, one can approximate the driving pressure, $\Delta p_{c}$, as the difference between the hydrostatic pressures of the air columns outside and inside the cave, $\Delta p_{c}=\left(\rho_{\text {out }}-\rho_{\text {in }}\right) g \Delta h$. Written in a more explicit form as a function of temperature, this gives:

$$
\Delta p_{c}=\frac{p_{0} M\left(T_{\text {in }}-T_{\text {out }}\right)}{R T_{\text {in }} T_{\text {out }}} g \Delta h
$$

where $\rho_{\text {out }}$ is the density of the outside air, $\rho_{\text {in }}$ is density of the inside air, $g$ is the gravitational acceleration, $p_{0}$ is the atmospheric pressure at the lower entrance, $M$ is the molar mass of dry air, and $R$ is the gas constant. This relationship assumes that the atmosphere is an isothermal incompressible ideal gas, which is appropriate for small height differences. In this notation, the sign of $\Delta p_{c}$ is positive in cold periods $\left(T_{\text {in }}>T_{\text {out }}\right)$ and negative in warm periods $\left(T_{\text {in }}<T_{\text {out }}\right)$. For temperature $|\Delta T|=\left|T_{\text {in }}-T_{\text {out }}\right|=20^{\circ} \mathrm{C}$, $T_{i n}=10^{\circ} \mathrm{C}$, and standard pressure $p_{0}=101.325 \mathrm{kPa}$, this approximation gives a driving pressure of about $0.9 \mathrm{~Pa} / \mathrm{m}$, which corresponds to about $90 \mathrm{~Pa}$ for an altitude difference of $100 \mathrm{~m}$ (Fig. 1).

Such small differences in pressure are difficult to measure directly, since the accuracy of barometers is usually in the range of a few hundred Pascals. Both airflow velocity and air temperature difference are routinely measured in caves and should display an approximately square-root relationship, $v \propto \sqrt{|\Delta T|}$, if ventilation is driven primarily by the chimney effect (Luetscher et al., 2008; Badino \& Chignola, 2019; Covington et al., 2021). Air density also changes with humidity and $\mathrm{CO}_{2}$ content, which has not been considered here as these corrections are relatively small for the given range temperature range.

The near-surface pressure variations caused by wind flow over the topography are not easy to estimate. They depend on local wind speed and direction, terrain morphology, and surface roughness. The drag and lift effects caused by the dynamic pressures of the wind generally increase with the square of wind speed, which is a consequence of Bernoulli's equation. In general, the wind or velocity pressure, $p_{w}$, has the form,

$$
p_{w}=\frac{1}{2} C_{p} \rho_{\text {out }} v_{w}^{2}
$$

where $C_{p}$ is a dimensionless coefficient containing the complexities associated with surface roughness, topography, and general flow pattern, and $v_{w}$ is the wind velocity. For simple cases, $C_{p}$ can be obtained from empirical calculations, while for more complex scenarios, computational fluid dynamics (CFD) simulations are commonly used (Zheng et al., 2018). The value of $C_{p}$ is between -1 and 1 (Zheng et al., 2018).

To elucidate the discussion, Figure 2 shows a very simple scenario of a cave crossing a hill between two entrances $E_{1}$ and $E_{2}$. In this case the wind will induce a positive pressure on the windward side (a positive sign in $C_{p}$ ) and a negative pressure on the leeward side (a negative sign in $C_{p}$ ). The driving pressure $\Delta p_{w}$ induced by the outside wind is equal to the difference of windinduced pressures measured at the two entrances $\Delta p_{w}=p_{w}^{E_{1}}-p_{w}^{E_{2}}$. Therefore, $\Delta p_{w}$ will have positive values when entrance $E_{1}$ is facing the wind and negative values when entrance $E_{2}$ is facing the wind. For the same standard pressure $p_{o}$ and temperature range $\left(-10^{\circ} \mathrm{C}\right.$ to $\left.30^{\circ} \mathrm{C}\right)$ as in the chimney flow estimation, a wind velocity $v_{w}$ and a conservative $C_{p}$ value of 0.5 (windward side in an open area), the wind induced pressures obtained from Eq. 2 reach $\sim 5.0 \pm 0.4 \mathrm{~Pa}$ at $v_{w}=4 \mathrm{~m} / \mathrm{s}$ and $\sim 70 \pm 5 \mathrm{~Pa}$ at $v_{w}=15 \mathrm{~m} / \mathrm{s}$. Since $v \propto \sqrt{\left|\Delta p_{w}\right|}$, for the turbulent flow, and $\Delta p_{w} \propto v_{w}^{2}$ the relationship between cave airflow velocity and external wind speed should be linear.

The similar magnitude of the pressure difference estimates of both driving mechanisms indicates that both mechanisms could be important, but their exact values remain speculative and uncertain due to the large number of unknowns and the high variation of wind speed and direction. We can assume that the total pressure difference between the cave entrances is equal to the contribution of both density- and wind-driven pressures, which leads us to $v \propto \sqrt{\left|\Delta p_{c}+\Delta p_{w}\right|}$. Depending on the sign, the pressure 


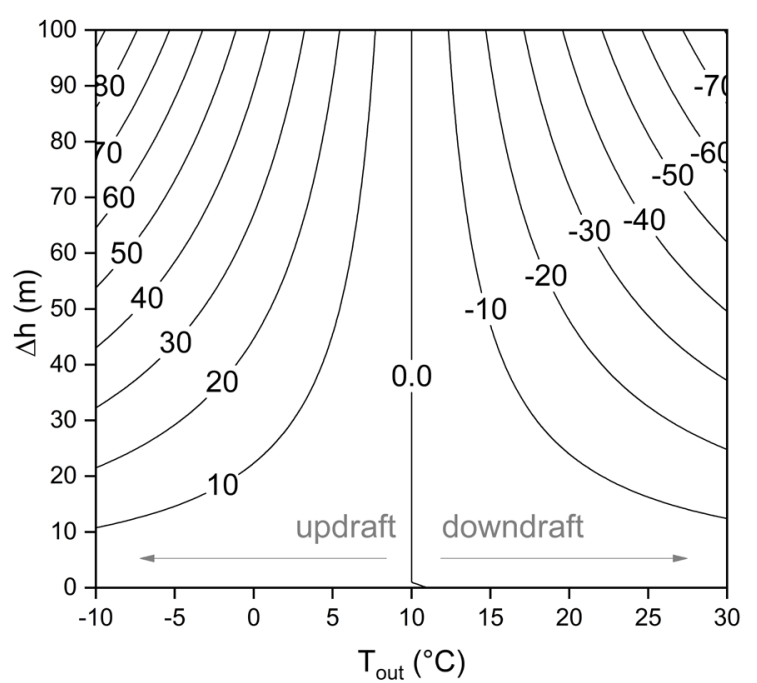

Fig. 1. Hydrostatic pressure variation as a function of outside temperature and altitude difference at $p_{0}=101.32$ $\mathrm{kPa}$ and $T_{\text {in }}=10^{\circ} \mathrm{C}$. A positive $\Delta p$ causes an upward airflow (updraft) in the system (air exits out from the upper entrance), while negative values cause a downward airflow (downdraft; air exits at the lower entrance).

differences generated by wind and the chimney effect may cancel each other out and reduce ventilation, or they may reinforce each other. Theoretically, this can be illustrated as four end-member cases, which are shown in Figure 2.

Note that Figure 2 shows an ideal scenario. In reality, the pattern of near surface wind velocity and induced pressure fields are very complex and can be only revealed by dense measurement network or appropriate modelling, as will be discussed latter.
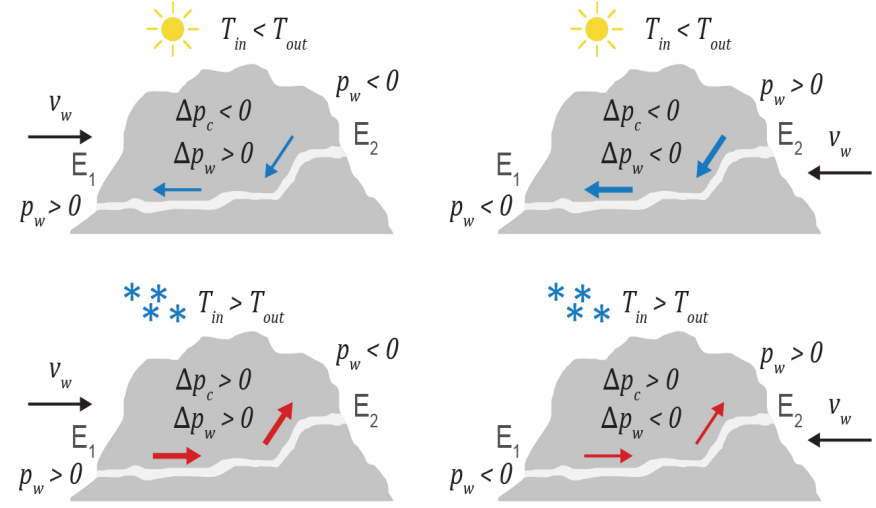

Fig. 2. Schematic representation of a cave within a karst massif under the influence of both density- and wind-driven ventilation. The two upper cases show a typical downdraft during a warm period conveying the air from the upper entrance, $\mathrm{E}_{2}$, toward the lower entrance, $E_{1}$, (red arrows). In the upper left case, $E_{1}$ is faced toward the wind, thus resulting in a lower total pressure difference $\Delta p$ between entrances. In the upper right case, the entrance $E_{2}$ is faced by the wind, which enhances the airflow driving force. The opposite occurs during the cooler period (two lower cases) when updraft dominates (blue arrows).

\section{STUDY SITE}

Postojna Cave is a cave system with five known entrances near Postojna, Slovenia (Fig. 3a), known primarily as a tourist attraction with a centurieslong history of tourism, an underground railway, and extensive passages richly decorated with speleothems (Šebela, 2019). The system extends over two dominant levels. The lower epiphreatic level is characterized by a perennial flow of the Pivka River, which sinks into the cave at the boundary between the Pivka Basin and the karst plateau (Fig. 3a). The upper level is a complex network of passages and breakdown chambers rich in speleothems and fluvial cave sediments. There are five known entrances to the system. The lowest main entrance (ME) is located on the south-facing escarpment about $20 \mathrm{~m}$ above the ponor. There are probably a number of other smaller and inaccessible openings that connect the cave network to the surface 30 to $100 \mathrm{~m}$ above (Šebela, 2010). This results in efficient ventilation throughout the year. In the cooler months, the cave is ventilated by upward air circulation (updraft), while in the warmer months downward air circulation (downdraft) prevails (Šebela \& Turk, 2011).

The easternmost side passages in Postojna Cave are Pisani Passage and Brezimeni Passage (Fig. 3c). Although they are of similar length ( 500 m) and both terminate by breakdown or flowstone choke, their microclimatic characteristics are quite different. The Brezimeni Passage (BP) has a large variation in air temperature $\left(\sim 2^{\circ} \mathrm{C}\right)$ and low, near-atmospheric $p \mathrm{CO}_{2}$ values, regardless of the ventilation regime, indicating a strong connection with the surface (Kukuljan et al., 2021). Pisani Passage (PP), on the other hand, is most likely connected to the surface by a dense network of narrow airflow pathways that efficiently damp air temperature variations and form a strong source of $\mathrm{CO}_{2}$ during warm periods (Gregorič et al., 2013; Prelovšek et al., 2018; Johnston et al., 2021).

The region surrounding the cave system contains mountain ranges of the Dinaric Alps, among which some peaks reach $1,000 \mathrm{~m}$ a.s.1. (Fig. 3a). The lowland between the mountains is a forested karst terrain densely populated with dolines of various sizes and origins (Fig. 4). Small solution dolines predominate, but large collapse dolines are important features, as their deepest points almost reach the level of active underground water flow. The ponor of the Pivka River is at $529 \mathrm{~m}$ a.s.1., while the water channels gradually descend towards the resurgence at Planina Cave to $453 \mathrm{~m}$ a.s.1. At the surface, above the central part of the system where most of the entrances are located, the terrain rises to a maximum of $633 \mathrm{~m}$ a.s.1., or about $100 \mathrm{~m}$ above the lowest, Main entrance. Postojna has a combination of subcontinental and sub-Mediterranean climate (Kozjek et al., 2017). The coldest month is January with an average temperature of $-0.1^{\circ} \mathrm{C}$ and the warmest is July with $19^{\circ} \mathrm{C}(1981-2010)$ (ARSO, 2021). The average annual precipitation is $1500 \mathrm{~mm}$.

The two main regional winds in SW Slovenia are the Bora and Jugo. Bora is a generally cold catabatic wind blowing from the north-northeast (NNE) towards the Adriatic coast (Rakovec et al., 2009). The Bora is particularly known for its gustiness, where the average speed can be exceeded by three times (Grisogono \& Belušić, 2009). Strong Bora events typically occur in the colder months, while the summer season is usually calmer. The Jugo is a southeasterly (SE) to southwesterly (SW) wind that carries moist air from the Adriatic Sea. Speeds reach up to $15 \mathrm{~m} / \mathrm{s}$ offshore and it has a similar occurrence and duration to the 


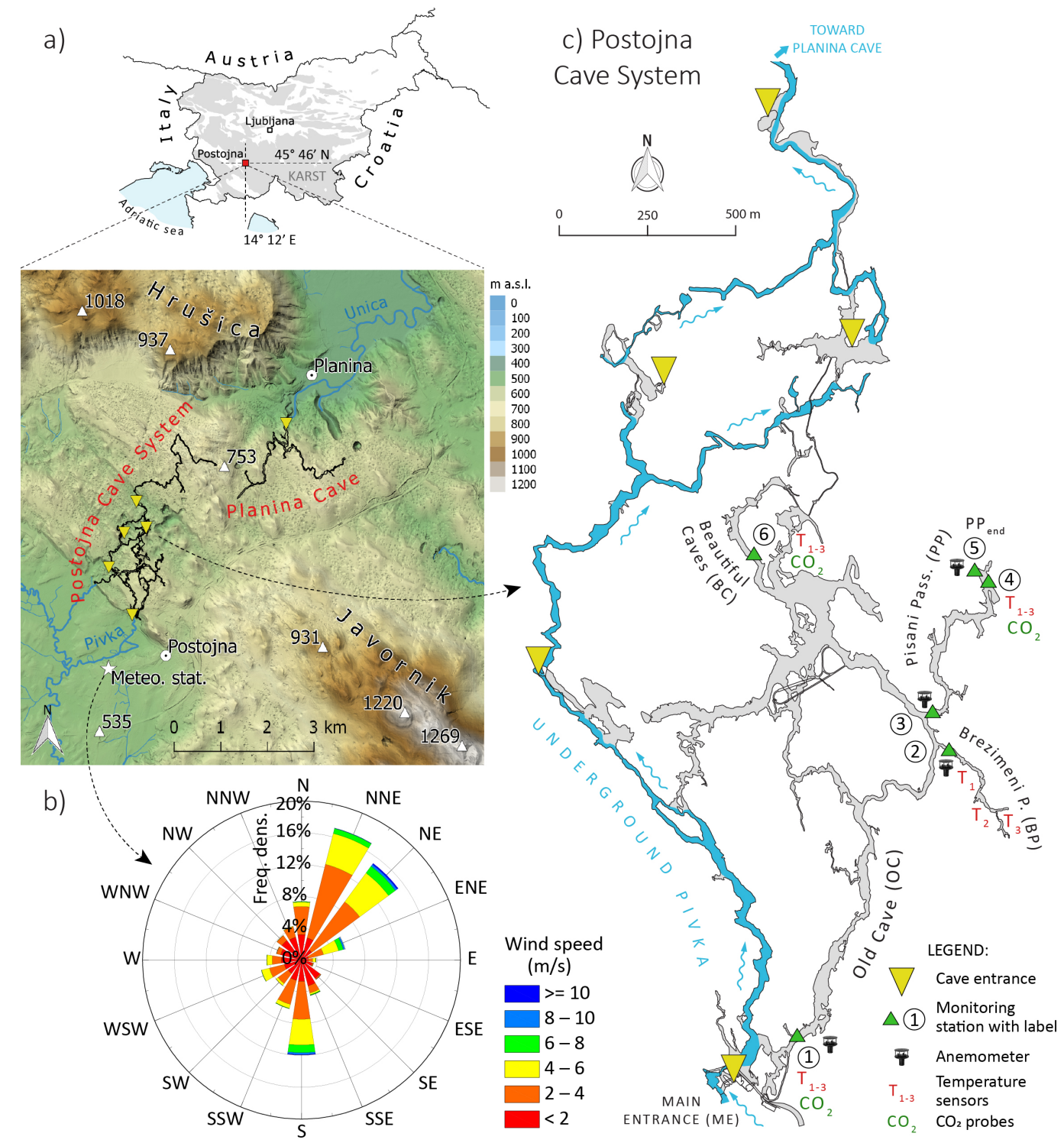

Fig. 3. a) Geographic location and terrain map of the Postojna region between the Hrušica Plateau and Javornik Hills. Black contour lines show the extent of cave passages and yellow triangles are cave entrances. The location of the national meteorological station is marked with a white star (S of Postojna Cave and W of Postojna). b) Wind-rose diagram of the national meteorological station with wind speed, direction and frequency density for the period 2017-2020 grouped into 16 bins. c) Map of Postojna Cave with continuous climate monitoring sites (modified from Kukuljan et al. (2021)). Map source: cave cadastre at the ZRC SAZU Karst Research Institute.

Bora. The average annual wind speed in Postojna is estimated at 3-4 m/s, while the surrounding ridges provide slightly higher values $(4-5 \mathrm{~m} / \mathrm{s}$ ) (Rakovec et al., 2009). Postojna is located at the foot of the orographic barrier and is therefore largely under the influence of $\mathrm{N}$ and $\mathrm{NE}$ winds. This is further enhanced by the topography, which channels air masses from inland (Fig. 4). A wind-rose diagram showing representative wind conditions in the Postojna region is shown in Figure 3b.

\section{MATERIALS AND METHODS}

A still active cave monitoring network was established in 2009-2012 in Postojna Cave System, mainly to determine the microclimate and assess the potential impact of tourism on the cave environment (Fig. 3c) (Gabrovšek et al., 2014; Mlakar et al., 2020). The backbone of the network consists of four meteorological stations (Microstep CMS) with temperature, $\mathrm{pCO}_{2}$ and airflow sensors. The stations are online, connected to a web server with data transmission via an optical cave line or via the Disruption Tolerant Network (DTN) protocol. A detailed description of the system and data management is available in Mlakar et al. (2020).

Station 1 was installed in a dominant airflow pathway near the main entrance to the cave (Old Cave, OC), stations $2-5$ in remote, unvisited locations (BP and PP), and station 6 in the location where the influence of visitors is most expected (Beautiful Caves, $\mathrm{BC}$ ). Stations 1, 3, 4, and 6 are connected to the web server via cable, while stations 2 and 5 record data by batteries. The stations record data at an interval of $1 \mathrm{~s}$ and record the statistics of the parameters with a resolution of $10 \mathrm{~min}$ : Ambient air temperature at three different heights with Pt100 sensors (stations $1,4$, and 6$), p \mathrm{CO}_{2}$ of the air $(1,4$, and 6$)$, and speed and direction of the airflow (1-4; Table 1). Ventilation through PP is monitored at its entrance (site 3 ; $\mathrm{PP}_{\text {ent }}$ ) and at its end ( 


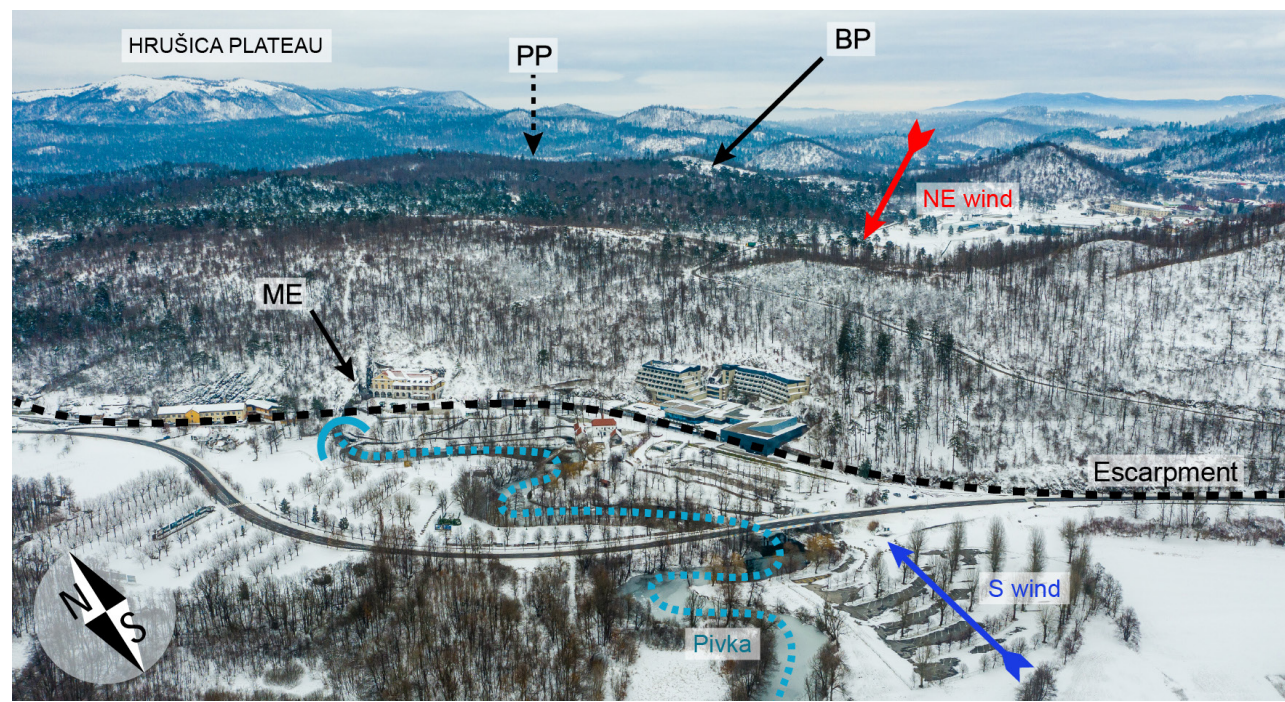

Fig. 4. Aerial view of the Main entrance (ME) of Postojna Cave and topography above the cave system showing the approximate positions of Pisani Passage (PP; behind the hill, not visible) and Brezimeni Passage (BP). The main wind directions are marked by red (NE) and blue (S) arrows. The escarpment is depicted with a black dashed line and the Pivka River with blue dashed line. The view is to the northeast. Geographic north is marked on the lower left.

Table 1. Summary of the equipment used in this study and its accuracy and measuring interval.

\begin{tabular}{|l|c|c|c|c|}
\hline \multicolumn{1}{|c|}{ Parameter } & Equipment & Resolution (Accuracy) & Measured interval & Comment \\
\hline $\begin{array}{l}\text { Airflow speed } \\
\text { and direction }\end{array}$ & $\begin{array}{c}\text { Gill Windsonic ultrasonic } \\
\text { anemometer }\end{array}$ & $\begin{array}{c}0.1 \mathrm{~m} / \mathrm{s} \pm 2 \% \text { at } 12 \mathrm{~m} / \mathrm{s}) \\
\text { and } 1^{\circ}\left( \pm 3^{\circ} \text { at } 20 \mathrm{~m} / \mathrm{s}\right)\end{array}$ & 10 min & $\begin{array}{c}\text { Connected or } \\
\text { battery powered }\end{array}$ \\
\hline Air temperature & $\begin{array}{c}\text { Pt100 sensor } \\
\text { HOBO MX2203 TidbiT }\end{array}$ & $\begin{array}{c}0.01^{\circ} \mathrm{C}\left( \pm 0.1^{\circ} \mathrm{C}\right) \\
0.01^{\circ} \mathrm{C}\left( \pm 0.2^{\circ} \mathrm{C}\right)\end{array}$ & $\begin{array}{c}10 \mathrm{~min} \\
10 \mathrm{~min}\end{array}$ & $\begin{array}{c}\text { Connected } \\
\text { Battery powered }\end{array}$ \\
\hline \multirow{2}{*}{$\mathrm{CO}_{2}$} & Vaisala GMP222 & $\begin{array}{c}10 \mathrm{ppm}( \pm 2 \% \text { of reading }) \\
1 \mathrm{ppm}( \pm 2 \% \text { of reading) }\end{array}$ & $\begin{array}{c}10 \mathrm{~min} \\
10 \mathrm{~min}\end{array}$ & $\begin{array}{c}\text { Range up to } 10,000 \\
\mathrm{ppm}\end{array}$ \\
\hline
\end{tabular}

the air is measured at two different heights, $6.5 \mathrm{~m}$ apart-one is near the floor, the other at the ceiling. Ambient air temperature in BP was measured offline with data loggers at three sites that have different microclimates.

Meteorological and climatic data of the outdoor conditions (air temperature and pressure, wind speed and direction at $10 \mathrm{~m}$ ) were obtained from the nearest national meteorological station $1.2 \mathrm{~km}$ SSW from the main entrance of the cave (Fig. 3b) (ARSO, 2021). The sampling rate is $10 \mathrm{~min}$ and the wind speed is available as an average value or as a maximum value (wind gust).

To evaluate $\Delta p_{w}$ between different entrances of Postojna Cave, the WindStation CFD model was used. The model simulates turbulent airflow over complex topography. It uses the control volume approach to integrate the discretized Navier-Stokes, mass conservation and energy equations, and a $k-$ $\varepsilon$ turbulence model. The model accounts for forests and other obstacles by adding source terms to the Navier-Stokes equation. The discretized equations are sub-relaxed and solved using the SIMPLEC algorithm. Details of the model are beyond the scope of this article. An interested reader can find more details on the algorithms and the use of the model in literature (Lopes, 2003). The modelling was carried out by Menzio $\mathrm{GmbH}$, the company responsible for the development and licensing of the software. The topography was provided as a grid file representing a digital elevation model (DEM) obtained from freely available $1 \mathrm{~m}$ resolution LiDAR scans (ARSO, 2020). The $10 \mathrm{~km} \times 10 \mathrm{~km}$ modelling domain covers a wider region around Postojna and Postojna Cave (virtually the entire area shown in Fig. 3b). The domain was discretized into cells with a planar dimension of 30 $\mathrm{m} \times 30 \mathrm{~m}$ and 40-50 vertical layers with a vertical range of $1.7 \mathrm{~km}$, resulting in 4.8 million nodes. The region above the cave was located in the central part of the modelling domain to minimize the influence of boundary conditions. A zero gradient boundary condition was used for the downstream boundary. Closed boundary conditions were used for the other three sides with no flow allowed to pass. The surface roughness is important for the results. The spatial distribution of the surface roughness was considered using a grid file with values of the aerodynamic roughness length $z_{0}$ over the entire domain. The roughness length was estimated based on the satellite image of the area. The forest model was active, with the forest height assumed to be a multiple of the roughness length. Given the surface topography, roughness, and boundary conditions, the model computed a steadystate solution for a given value of wind speed and direction at the meteorological station. We used 12 directions at $30^{\circ}$ intervals with wind speeds ranging from $2-20 \mathrm{~m} / \mathrm{s}$ in $2 \mathrm{~m} / \mathrm{s}$ increments. A total of 120 simulations were performed.

\section{RESULTS AND DISCUSSION}

\section{Cave climate conditions}

Figure 5 shows the typical seasonal pattern of microclimate parameters observed at all five climate monitoring sites in Postojna Cave during the study period (2017-2020). Sites close to the main airflow pathways, such as OC, were subject to a larger 
variation in air temperature $\left(7^{\circ} \mathrm{C}\right)$ than the inner parts of the cave, such as $\mathrm{BC}\left(0.8^{\circ} \mathrm{C}\right)$ or $\mathrm{PP}\left(0.1^{\circ} \mathrm{C}\right)$. Ambient air temperature measurements showed irregularity in the cave, with PP being on average the coldest location $\left(8.8^{\circ} \mathrm{C}\right)$, and $\mathrm{BP}$ the warmest location $\left(10.8^{\circ} \mathrm{C}\right)$. The airflow time series (Fig. $5 \mathrm{~b}$ ) distinguishes three different cave ventilation regimes: Winter, summer and transitional. In cold periods, the cave air is lighter than the outside air and flows upwards towards higher entrances and openings (updraft, positive sign), while in warm periods the cave air is denser, flowing downwards and out of the lowest main entrance (downdraft, negative sign). When the outside temperature is close to the cave temperature, daily transitions between ventilation regimes can be observed. Because the air temperature in the cave varies by a few degrees, the change in airflow direction does not occur simultaneously throughout the cave.

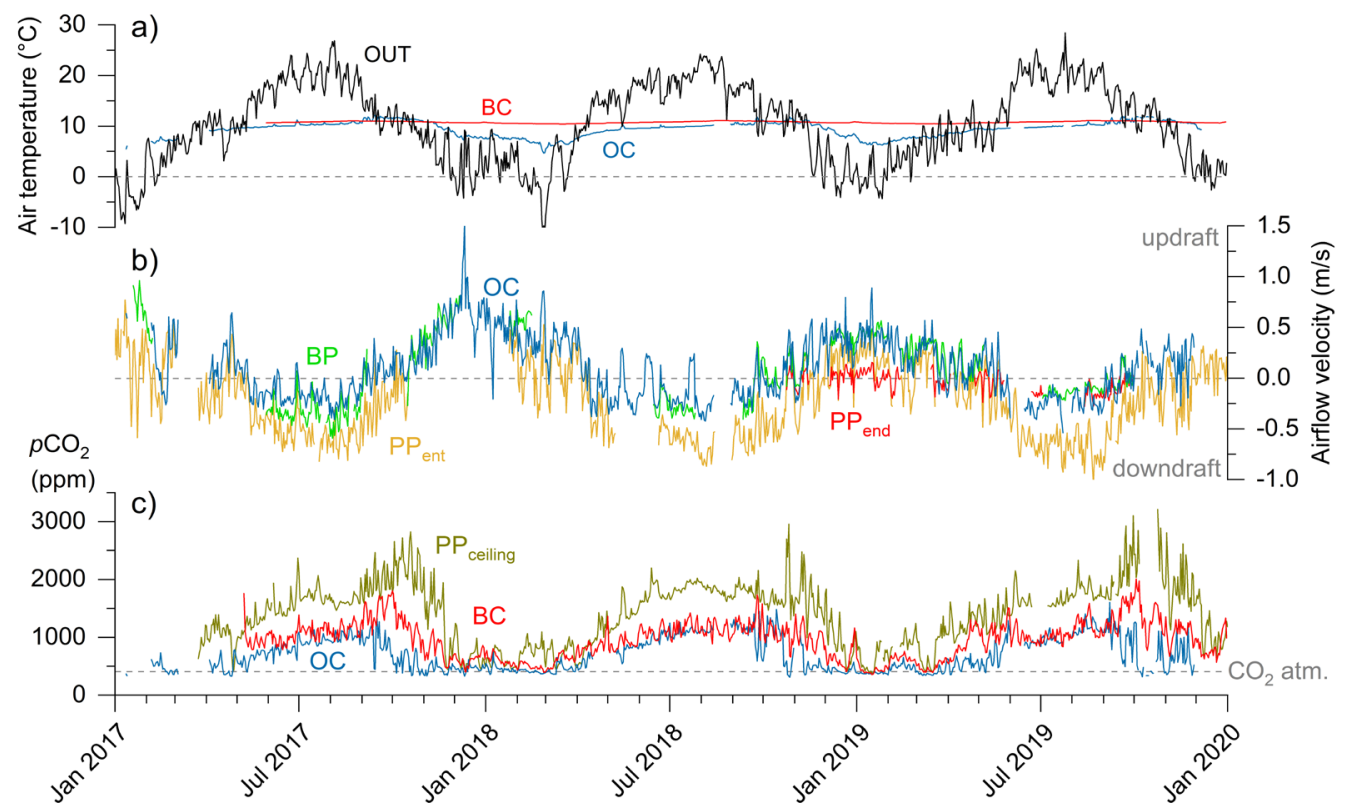

Fig. 5. Time series of Postojna Cave climate data for the entire study period (daily values): a) temperature variation in the cave compared to the outside temperature, b) airflow velocities recorded in Pisani Passage, Brezimeni Passage, and Old Cave with negative values for a downdraft and positive values for an updraft, and c) $\mathrm{pCO}_{2}$ time series recorded in Pisani Passage (ceiling), Beautiful Caves and the Old Cave. The value of $410 \mathrm{ppm}$ was taken as the atmospheric $p \mathrm{CO}_{2}$ value (NOAA/ESRL, 2021).

Moreover, while the seasonal variation is clearly visible, the airflow and $p \mathrm{CO}_{2}$ signals have a distinctly jagged appearance that does not exactly follow the variation in $\Delta T$. Such behavior can occasionally occur even during periods when $|\Delta T|$ is $>10^{\circ} \mathrm{C}$, which would otherwise cause strong chimney flow. In our previous study (Kukuljan et al., 2021), we suggested that these brief interruptions, i.e., the temporary reversal of expected airflow directions, can be largely attributed to the action of outside winds. As an example, Fig. 6 shows airflow velocities at $\mathrm{PP}_{\text {ent }}$ for 2017-2020 plotted against the outside temperature. The original data set (red points) is widely scattered. However, when windy periods are filtered out, a square-root relation between airflow speed and $T_{\text {out }}$ emerges and results in a better fit $\left(R^{2}=0.8487\right.$ compared to $\left.R^{2}=0.5049\right)$. This is shown by green and blue points representing records when the outside wind speed was below $3 \mathrm{~m} / \mathrm{s}$ and $1 \mathrm{~m} / \mathrm{s}$, respectively.

\section{Wind characteristics}

The wind-rose diagram in Figure $3 \mathrm{~b}$ shows that the three predominant wind directions in Postojna are north $(\mathrm{N})$, north-northeast (NNE) and northeast (NE), representing the Bora wind, followed by south (S) and south-southwest (SSW), representing the Jugo wind. The distribution of these directions changes only slightly across seasons (Fig. 7a). The Bora (from now simplified as "NE wind") is active throughout the year, while the Jugo (hereafter "S wind") has a lower prevalence during the summer months and an overall lower prevalence during the year compared to the Bora. The distribution of wind speed also changes only slightly, but the average wind speed is generally higher in winter $(3.1 \mathrm{~m} / \mathrm{s})$, than in summer $(2.3 \mathrm{~m} / \mathrm{s})$.

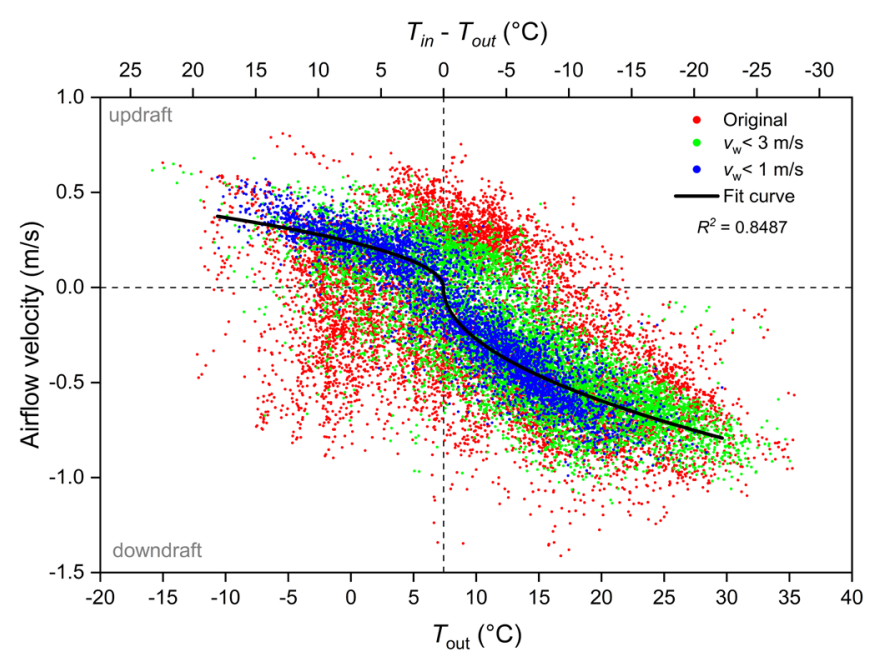

Fig. 6. Airflow velocity measured at PPent plotted against outside temperature. Two filtering criteria were used: red points include all data points, green points those when $v_{w}<3 \mathrm{~m} / \mathrm{s}$, and blue points those when $v_{w}<1 \mathrm{~m} / \mathrm{s}$. The clearest chimney flow relationship and best square root fit $\left(R^{2}=0.8487\right)$ is obtained when windy periods are excluded (black curve). Note that Tin was left to be determined by the fitting function $\left(7.4^{\circ} \mathrm{C}\right)$ based on which the upper $\mathrm{x}$-axis was able to be defined. 
Figure $7 \mathrm{~b}$ shows the variations in wind speeds between two main wind sectors on a monthly basis. NE winds are generally the strongest throughout the year, with an average speed of $3.5 \mathrm{~m} / \mathrm{s}$, while $\mathrm{S}$ winds are weaker (average $2.6 \mathrm{~m} / \mathrm{s}$ ). The winds also show daily variation in speed and direction, but this variability has not been studied in detail.

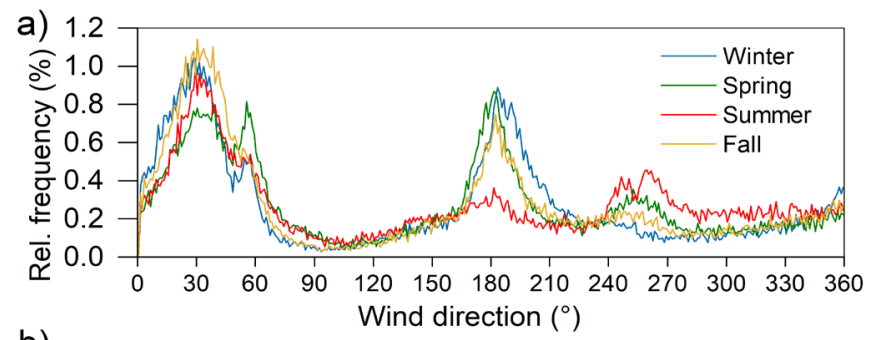

b)

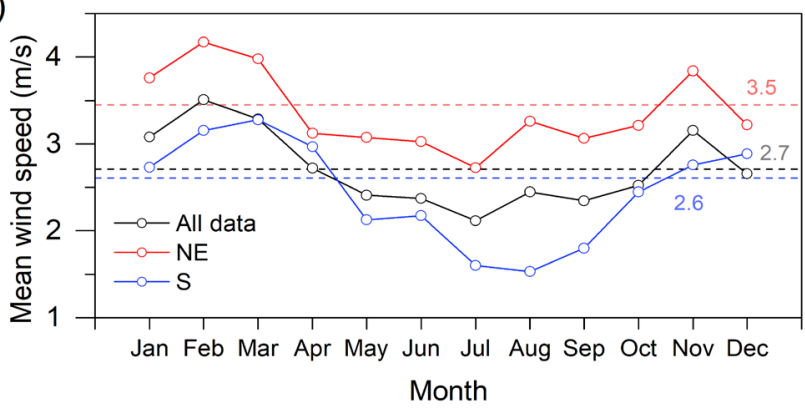

Fig. 7. a) Frequency distribution of wind direction for 2017-2020 grouped by season: Dec, Jan, and Feb (blue curve), Mar, Apr, and May (green curve), Jun, Jul, and Aug (red curve), and Sept, Oct, and Nov (yellow curve). b) Mean wind speeds for NE, S and all winds combined on a monthly basis. Dashed lines correspond to absolute means labelled with values.

\section{Estimation of wind pressure field above Postojna Cave}

Figure 8 shows the results of the WindStation model for the velocity and pressure field over Postojna Cave System, when wind speed and direction at the meteorological station are $v_{w}=10 \mathrm{~m} / \mathrm{s}$ and $\phi=30^{\circ}$ (NNE wind, Fig. $8 \mathrm{a}$ and $\mathrm{b}$ ) or $v_{w}=10 \mathrm{~m} / \mathrm{s}$ and $\phi=180^{\circ}$ (S wind, Fig. 8c, d). The model computes the velocity pressure field relative to a reference point in the domain, where it is taken to be zero. Since we are interested in pressure differences between selected points (e.g., location of cave entrances), this result is sufficient. Note that when the wind speed is zero, the values of $p_{w}$ in the entire domain are zero. In Figures $8 \mathrm{a}$ and $8 \mathrm{c}$, the pressure field is uniformly shifted so that the zero value is in the region of the main entrance ME. The black isobars are used for positive values and the red isobars for negative values; that is, black regions have $p_{w}$ greater than $\mathrm{ME}$ and red regions less. A brief review shows that $\Delta p_{w}$ can reach several hundred Pascals between different locations, which is comparable to or higher than the pressure differences calculated for the chimney effect. Airflow is diverted and/or channeled by topography, which also determines regions with higher and lower wind pressures.

In $\mathrm{NE}$ winds, the depression near the terminal part of Pisani Passage (PP) has a higher pressure than the region around the main entrance, while the region above the terminal part of Brezimeni Passage (BP) has a negative pressure. The scarp between the Pivka Basin and the karst plateau plays a particularly important role in $\mathrm{S}$ winds. Most of the area NE of the scarp where the cave system extends has a lower pressure than the pressure around the main entrance.

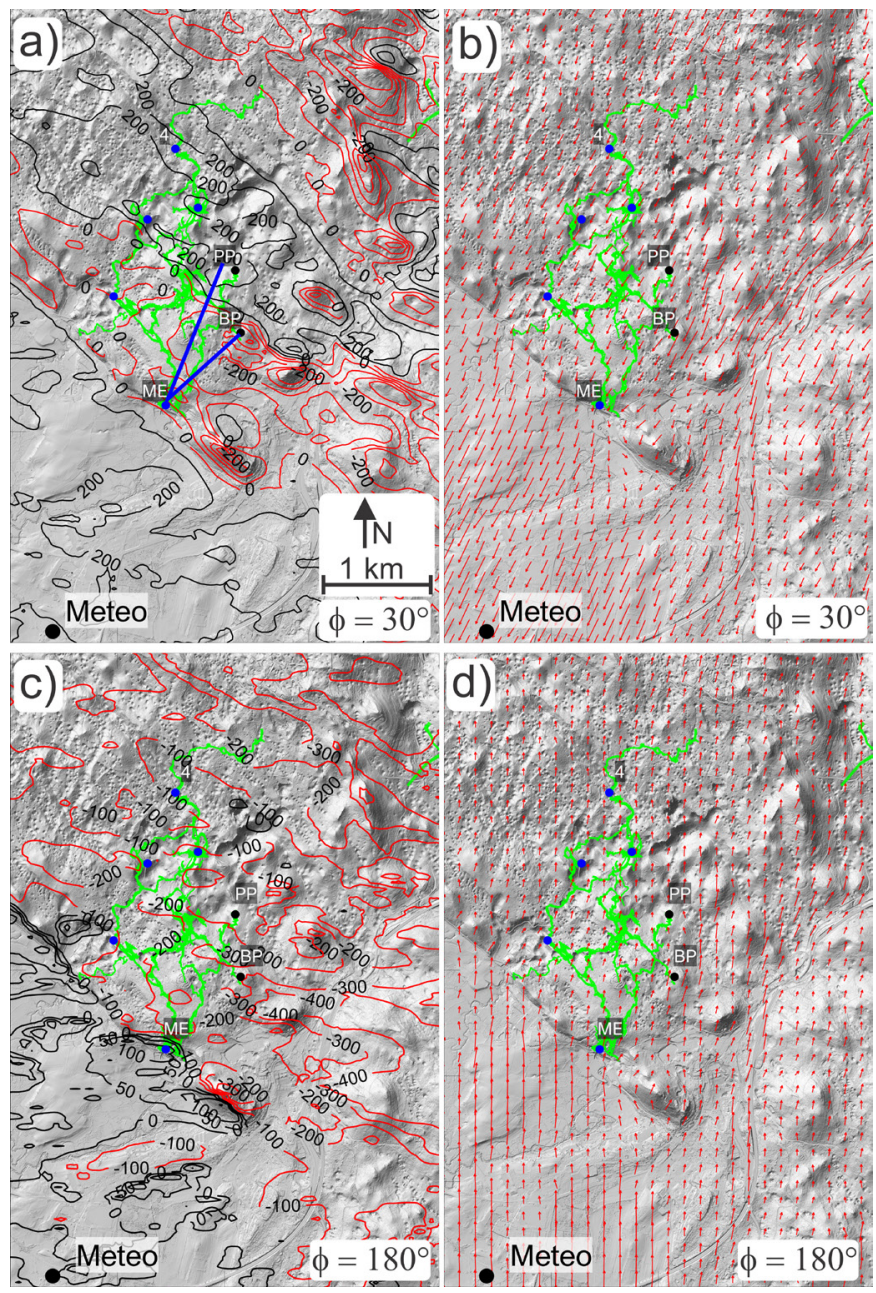

Fig. 8. Contour map of the wind pressure field in Pascals for different values at the meteorological station: (a) $v_{w}=10 \mathrm{~m} / \mathrm{s}$ and $\phi=30^{\circ}$ and (c) $v=10 \mathrm{~m} / \mathrm{s}$ and $\phi=180^{\circ}$, and vector field map of wind velocity for: (b) $v_{w}=10 \mathrm{~m} / \mathrm{s}$ and $\phi=30^{\circ}$ and (d) $v_{w}=10 \mathrm{~m} / \mathrm{s}$ and $\phi=180^{\circ}$. The green polygon marks the extent of the Postojna Cave passages. Black points and labels mark the positions of the meteorological station and terminal part of Pisani Passage (PP) and Brezimeni Passage (BP). The positions of the known cave entrances are marked by blue points, while the main entrance is also labelled (ME). The blue lines in (a) denote the profiles ME-PP and ME-BP (see Fig. 9).

To further illustrate the modelling results, we plot velocity/pressure profiles along two lines for different wind speeds and directions in Figure 9. The profiles, shown in Figure 8a, connect the region above the terminal parts of $\mathrm{PP}$ and $\mathrm{BP}$ and the Main entrance (ME-PP and ME-BP). Figure 9a shows the wind speed and pressure $5 \mathrm{~m}$ above the ground along the line $\mathrm{ME}-$ $\mathrm{PP}$ for a wind direction of $30^{\circ}(\mathrm{NNE})$ and for different values of wind speed at the meteorological station $(4$, $6,8$, and $10 \mathrm{~m} / \mathrm{s})$. The grey shading represents the topography along the profile. $\Delta p_{w}$ between $\mathrm{ME}$ and PP increases approximately with the square of wind speed. Figure $9 \mathrm{~b}$ shows the same profile for the $\mathrm{S}$ wind $\left(\phi=180^{\circ}\right)$, where the wind-driven effect drives cave ventilation in the opposite direction with similar pressure differences between the ends of the profiles as for the $30^{\circ}$ case.

The wind pressure distribution was also estimated for other directions. Figure $9 \mathrm{c}$ shows the $p_{w}$ along 
the profile $\mathrm{PP}-\mathrm{ME}$ for all directions in $30^{\circ}$ steps at $5 \mathrm{~m}$ height and $v_{w}=10 \mathrm{~m} / \mathrm{s}$. The largest differences between minimum and maximum $p_{w}$ are found at $30^{\circ}$ and $150^{\circ}$, and the smallest at $120^{\circ}$ and $330^{\circ}$ when the winds blow parallel to the escarpment. The wind pressure in the profile ME-BP is shown in Figure
$9 \mathrm{~d}$ for both $\phi=30^{\circ}$ and $\phi=180^{\circ}$. Here, the wind pressure differences between $\mathrm{ME}$ and $\mathrm{BP}$ are smaller than at PP due to the different topography. For both wind directions, $\Delta p_{w}$ between the main entrance and the surface above the BP is positive, with a higher pressure difference for $\mathrm{S}$ winds. a) ME-PP $\left(\phi=30^{\circ}\right)$

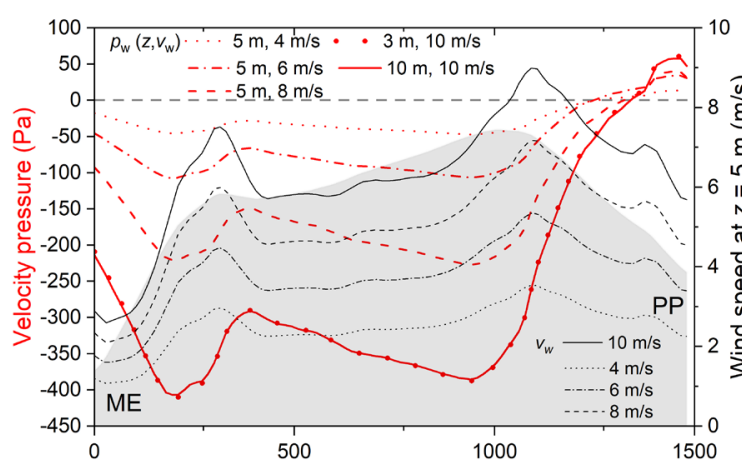

c) ME-PP (all directions)

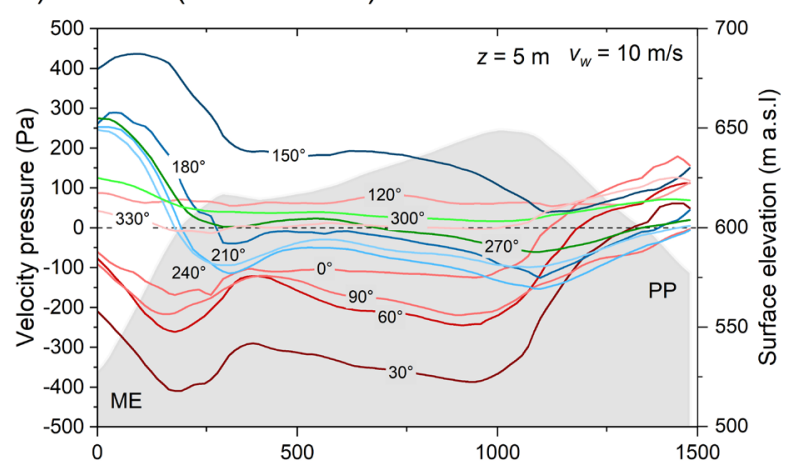

b) ME-PP $\left(\phi=180^{\circ}\right)$
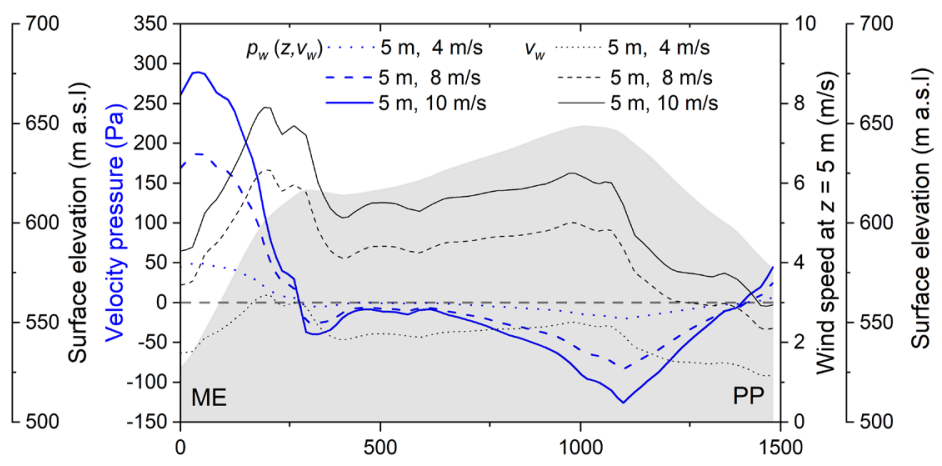

d) ME-BP

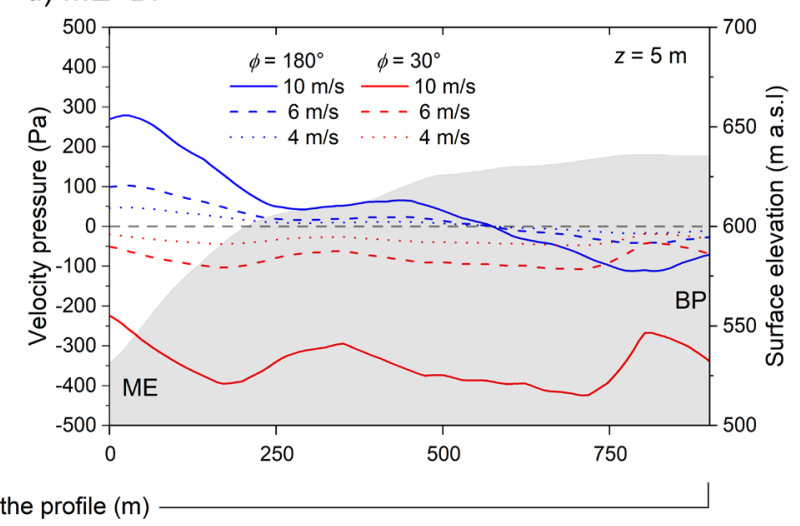

Fig. 9. Velocity pressure profiles along ME-PP with $\phi=30^{\circ}(\mathrm{a})$ and $\phi=180^{\circ}$ (b) for different wind speeds at the meteorological station $(4-10 \mathrm{~m} / \mathrm{s})$. Velocity pressure profiles along ME-PP for all wind directions at $30^{\circ}$ increments (c). d) Velocity pressure profile along MEBP for $\phi=30^{\circ}$ and $\phi=180^{\circ}$ for different wind speeds at the meteorological station $(4,6$, and $10 \mathrm{~m} / \mathrm{s})$.

The results of the CFD model, although quantitative, must be considered with some caution. The exact numerical value of $p_{w}$ is the result of several empirical assumptions that are incorporated in the model. We have also neglected the fact that the pressure at the ground, where the entrances are located, is in fact not calculated, since the wind profile is only valid for $z>z_{0}$. In addition, the domain discretization does not allow us to account for small-scale surface irregularities, which certainly affect the local wind field.

\section{Relationship between cave ventilation and wind}

Seasonal variations in cave airflow direction indicate that the predominant mechanism of ventilation in Postojna Cave is the chimney effect. Wind-driven pressure differences can either increase or decrease the ventilation, and in extreme cases, even reverse its direction. To illustrate this effect more clearly, we compared cave conditions (airflow and temperature) and outside conditions (wind speed/direction and temperature) in shorter, 20-day windows. Figure 10a shows a cold period (when generally $T_{\text {in }}>T_{\text {out }}$ ), and Figure $10 \mathrm{~b}$ shows a warm period (when generally $T_{\text {in }}<T_{\text {out }}$ ). For $T_{i n}$ we use the air temperature at PP (site 4), since this site has the most stable temperature signal. To represent wind direction, we choose a convention where the outside wind velocity has a positive sign for directions between $90^{\circ}$ and $270^{\circ}$ and a negative sign for directions above $270^{\circ}$ and below $90^{\circ}$. The wind time series has been colored according to the two most prominent directions- $\mathrm{NE}$ winds are colored red, S winds are colored blue, while all others are colored gray.

In Figure 10a, which represents a cold period, a dominant updraft driven by the chimney effect is interrupted by short bursts of downdrafts. When the winds come from the $\mathrm{NE}$, the airflow in the cave will decrease or, if the wind is strong enough, it can cause a complete reversal of the cave airflow direction (red arrows). Similarly, S winds will increase the updraft velocity (blue arrow). In warm periods, the effect is the opposite (Fig. 10b). In a period dominated by downdraft, the NE wind increases the airflow speed, while the S wind decreases it or even reverses it into an updraft. In these two end-member cases, the value of $|\Delta T|$ can sometimes exceed $10^{\circ} \mathrm{C}$, which would typically cause a strong chimney effect. Despite this, however, for a short period of time, the cave can ventilate in the opposite direction of the flow expected by the chimney effect. The onset, duration, and termination of these events closely follow the wind events, and the effect can be observed at each of the monitoring sites, albeit with varying intensity and pattern. 
a) cold period

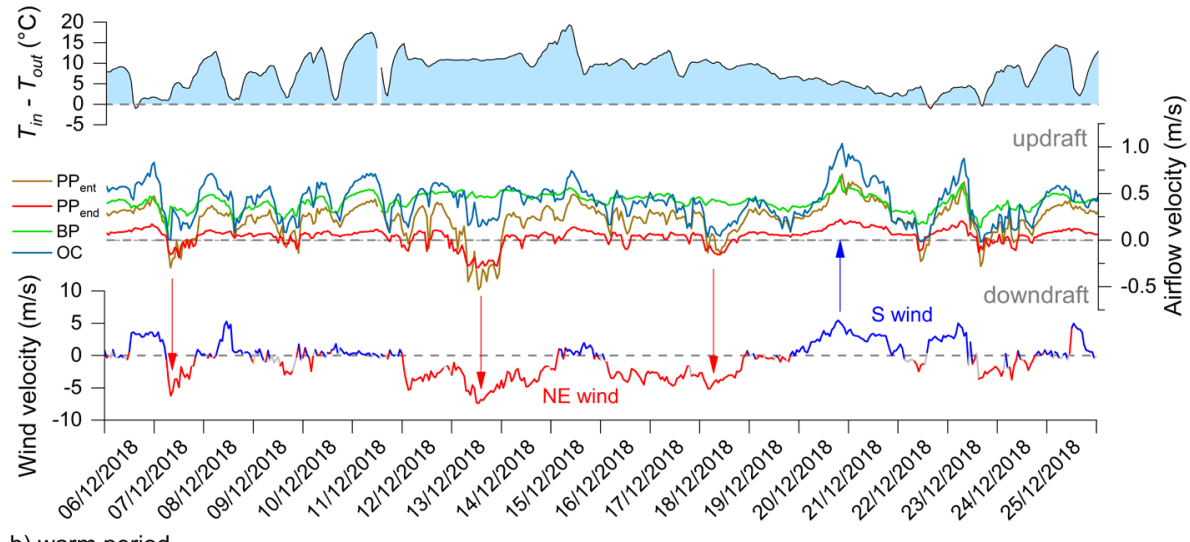

b) warm period

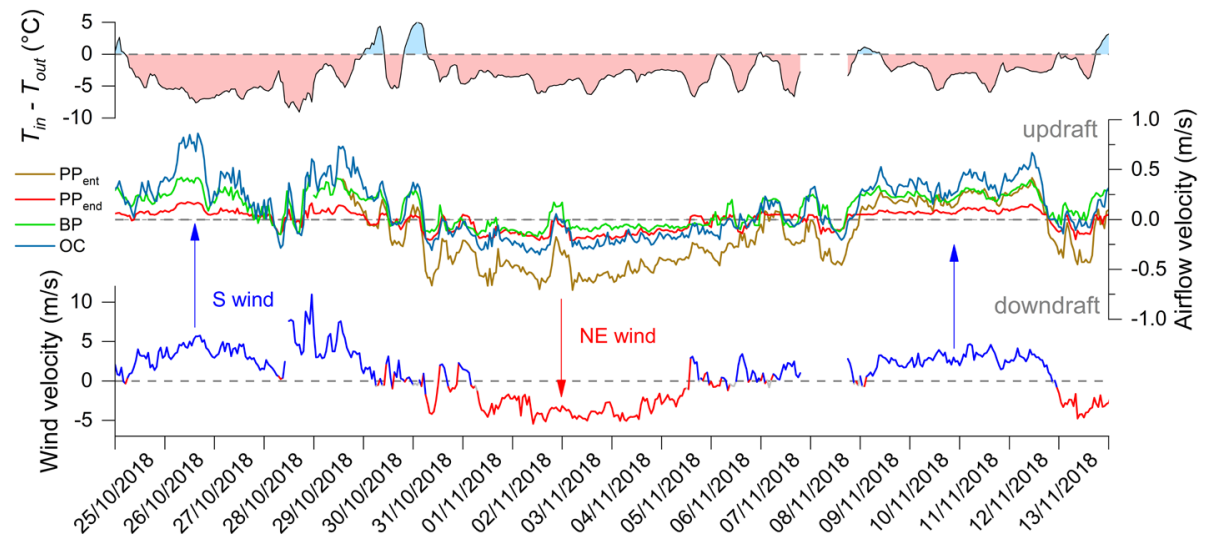

Fig. 10. Dynamics of airflow at Postojna Cave (center) as a function of temperature difference (top) and outside wind speed and direction (bottom) for the 20-day cold (a) and warm (b) periods. The airflow velocity time series (middle) are colored by location- $\mathrm{PP}_{\text {ent }}$ is yellow, $\mathrm{PP}_{\text {end }}$ is red, BP is green, and the $\mathrm{OC}$ is blue. Wind speed is colored as a function of direction-positive signs are given to all winds with directions from $90-270^{\circ}$, and negative for those coming from above $270^{\circ}$ and below $90^{\circ}$. The time series are additionally colored by wind sector-winds from $330-90^{\circ}$ are colored red, winds from $120-270^{\circ}$ are colored blue, and all others are colored gray. Red arrows show the influence of the NE wind on the cave airflow, while the blue arrows represent the influence of the S wind.

The wind-driven effect is also evident when analyzing daily resolution data from the entire 2017-2020 study period. In Figure 11, airflow velocity has been plotted against outside temperature for the most windprone site, $\mathrm{PP}_{\text {ent }}$. Red points indicate the days with prevailing $\mathrm{NE}$ winds, while blue points represent the days with prevailing $\mathrm{S}$ winds. These observations are consistent with the results of the model presented in the previous chapter. The NE wind induces a negative $\Delta p_{w}$ between the lower and upper entrance, thus promoting a downdraft. On the other hand, S winds induces a higher pressure at the lower entrance (ME) and therefore promote an updraft.

The $T_{\text {in }}$ in Figs 6 and 11 are different to each other and to the measured temperature in PP. The $T_{i n}$ in both figures is obtained from the fit, where point clouds used in both fits differ; in Figure 6 the actual values sampled in 10 min resolution for cases with $v_{w}<3 \mathrm{~m} / \mathrm{s}$ are used, while the average daily values are used in Figure 11. Furthermore, note that the Pisani Passage is only a part of the ventilation pathway and that the measured temperature in PP $\left(8.8^{\circ} \mathrm{C}\right)$ is therefore not completely representative. Some differences may be related to the composition of cave air, which has not been considered here. Although these discrepancies are not important for the present discussion, we mention them to avoid confusion and provoke further research.

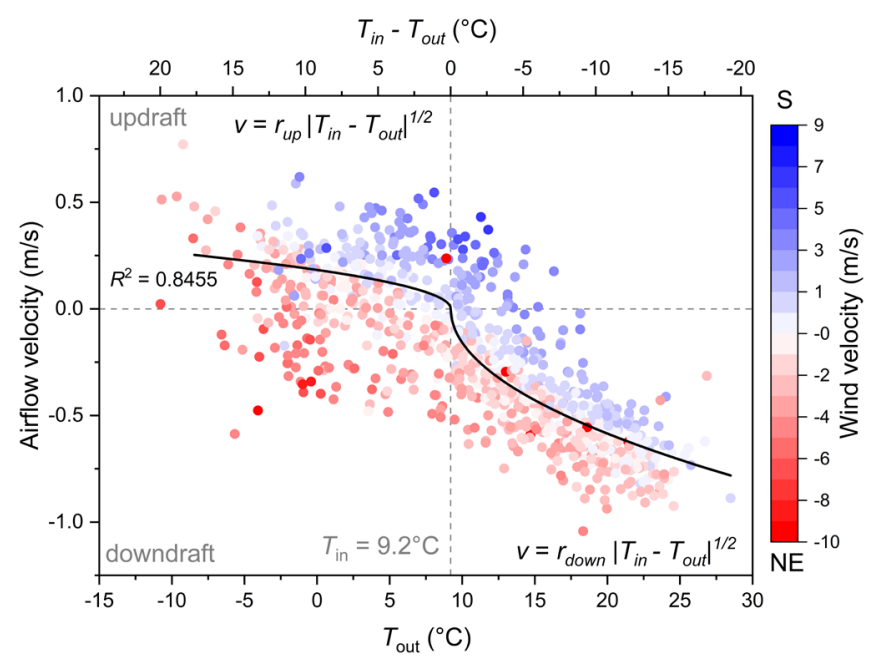

Fig. 11. The plot of daily average airflow velocity at $\mathrm{PP}_{\text {ent }}$ against outside temperature, color-coded by outside wind speed and direction. The days with prevailing NE winds are colored red, while $\mathrm{S}$ winds are colored blue. Stronger color means stronger mean wind speed. The square-root relationship (black curve) was fitted only with calm days $\left(v_{w}<2 \mathrm{~m} / \mathrm{s}\right)$. The red and blue points are well separated, indicating that wind direction has a consistent and predictable effect on cave airflow-NE winds enhance the downdraft, while $S$ winds enhance the updraft. The effect scales well with wind speed and shows greater scattering (deviation) from the theoretical relationship on windy days. 


\section{Spatial differences in the wind-driven effect}

The wind-driven effect is observed at all sites (Fig. 10a, b). However, the data show that the effect varies from site to site. For example, OC and BP respond more strongly to $\mathrm{S}$ winds, while sites in $\mathrm{PP}$ respond strongly regardless of wind direction. To best identify the wind-driven effect, we filtered the hourly cave airflow velocity to select data when $T_{\text {in }} \approx T_{\text {out }}$ to minimize the contribution of chimney effect. The filtered data are shown in Figure 12 for three sites.
In the case of $\mathrm{PP}_{\text {ent }}$, the outside temperature range of $8-10^{\circ} \mathrm{C}$ was taken as the filter criterion (about $\pm 1^{\circ} \mathrm{C}$ from the theoretical value in Figure 11). A linear correlation was calculated separately for $\mathrm{NE}$ and $\mathrm{S}$ winds (both at $v_{w}>1 \mathrm{~m} / \mathrm{s}$ ). The same procedure was repeated for $\mathrm{OC}^{\circ}\left(8^{\circ} \mathrm{C}<T_{\text {out }}<10^{\circ} \mathrm{C}\right)$ and $\mathrm{BP}\left(10^{\circ} \mathrm{C}<\right.$ $T_{\text {out }}<12^{\circ} \mathrm{C}$ ). For both BP and $\mathrm{OC}$, a positive linear correlation is obtained only with updraft and $\mathrm{S}$ winds, while NE winds showed weak or no correlation with cave airflow (Fig. 12).
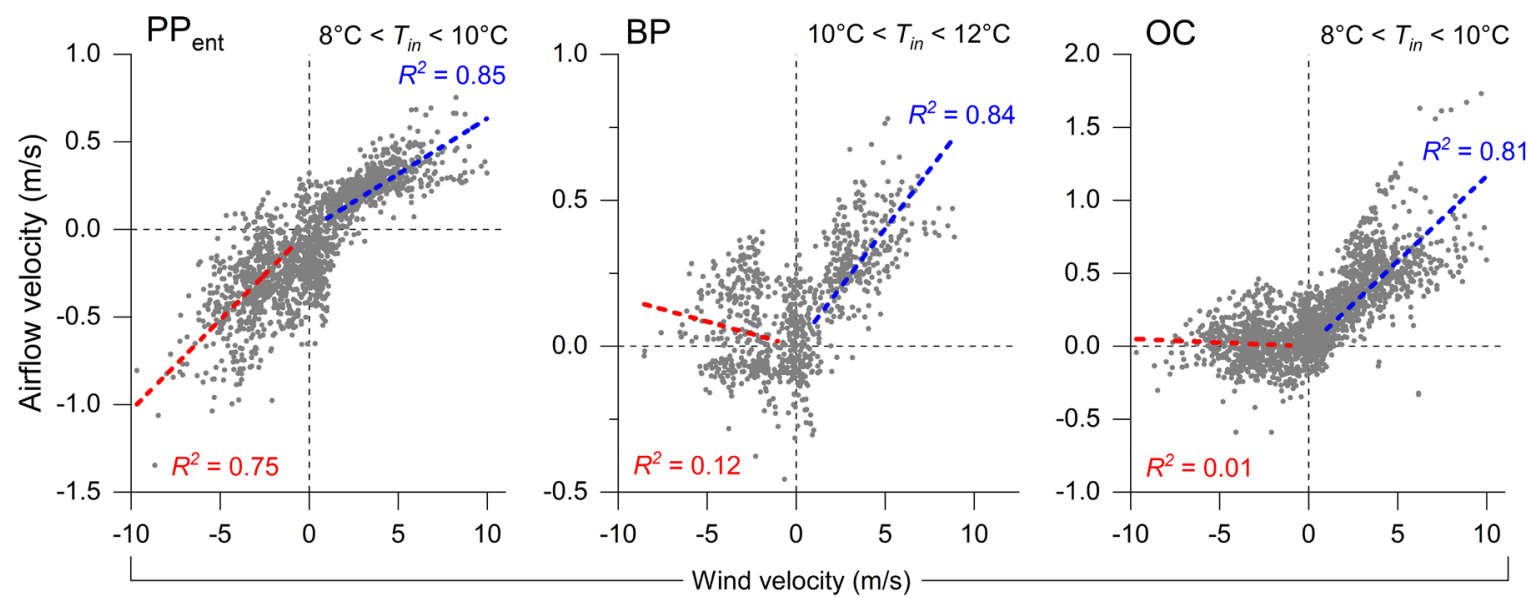

Fig. 12. Linear relationships between hourly wind velocities and airflow velocities: Pisani Passage (PP ), Brezimeni Passage (BP), and Old Cave (OC) at Postojna Cave in a bounded temperature range when $T_{\text {in }} \approx T_{\text {out }}$ is between $8-10^{\circ} \mathrm{C}$ (for $\mathrm{PP}_{\text {ent }}$ and $\mathrm{OC}$ ), and $10-12^{\circ} \mathrm{C}$ (for $\mathrm{BP}$ ). The linear regressions were calculated for wind speeds greater than $1 \mathrm{~m} / \mathrm{s}$.

Many factors may contribute to the spatial diversity of airflow patterns: the relative position of the measurement site within the cave airflow pathway, its proximity to the nearest cave entrance, the orientation and size of the entrance, and the position of the entrances within regional wind flows and topography. The spatial differences discussed are in agreement with the results of the CFD model. When comparing different topographic velocity pressure profiles, the model gives higher pressure differences for the ME$\mathrm{BP}$ profile than for the ME-PP profile for the $\mathrm{S}$ wind (Fig. 13). When considering the effect of NE wind, the sign of the wind pressure depends on the profilealong ME-PP a downdraft is forced, while along ME$\mathrm{BP}$ an updraft is forced.

$\mathrm{OC}$ and $\mathrm{BP}$ show similar airflow characteristics. BP is found to be the main pathway connecting the main entrance, OC and the surface (Fig. 3). The height difference between the passage and the surface above is about $100 \mathrm{~m}$ in the case of $\mathrm{BP}$ and $40 \mathrm{~m}$ in the case of PP. Thus, the chimney effect in BP is much stronger and the wind-driven effect is less pronounced than in PP. Moreover, the airflow between BP and the surface is concentrated in a large vertical passage (chimney). High temperature variations and low $\mathrm{CO}_{2}$ content in the passage between the chimney and the connection to $\mathrm{OC}$ during the downdraft indicate a good airflow connection to the surface (Kukuljan et al., 2021). On the other hand, no dominant airflow pathway toward the surface was found in PP. These differences are also reflected in the average volumetric flow rate - it is about $3.4 \mathrm{~m}^{3} / \mathrm{s}$ in $\mathrm{BP}$ compared to $0.5 \mathrm{~m}^{3} / \mathrm{s}$ in $\mathrm{PP}$.

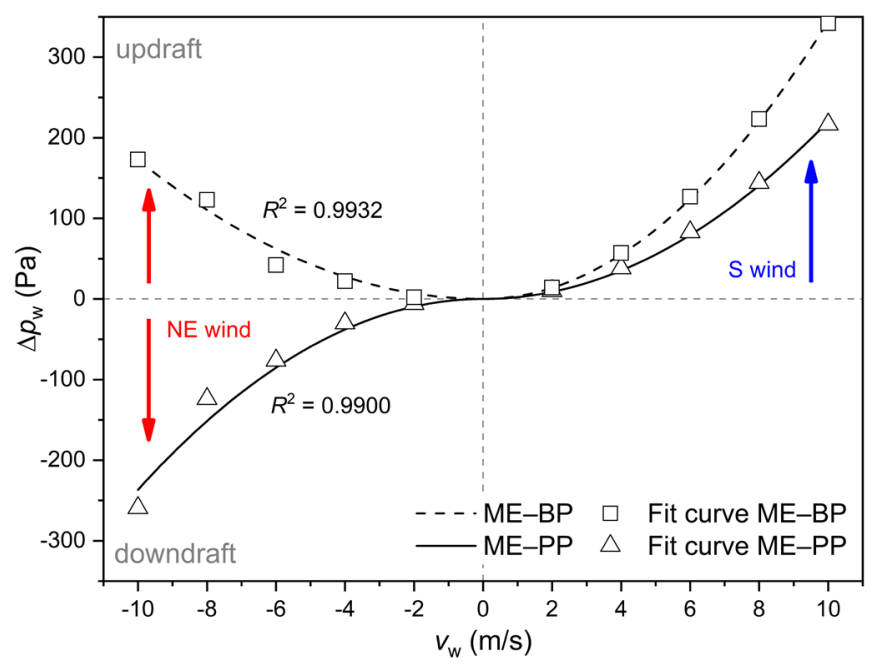

Fig. 13. Wind pressure differences between the Main entrance (ME) and Pisani Passage (PP; triangles) or Brezimeni Passage (BP; squares) determined by the CFD model as a function of wind velocity. The points are fitted with a quadratic function, $\Delta p_{w}=c_{w} v_{w}^{2}$ and the fit quality is quantified using $R^{2}$. S wind forces an updraft in both profiles, while NE wind forces an updraft in the ME-BP profile and a downdraft in the ME-PP profile.

\section{Scale and frequency of the wind-driven effect}

The CFD model produces the expected qualitative results, but the question remains how reliable the quantitative predictions are. In this section, we compare the magnitude of the pressure differences between PP and ME, derived from observations and calculated by the CFD model. The model results are shown in Figure 13 and Table 2, which give values of $\Delta p_{w}=p_{w}{ }^{\mathrm{ME}}-p_{w}{ }^{\mathrm{PP}}$ for wind speeds between $2-10 \mathrm{~m} / \mathrm{s}$ 
and directions $\phi=30^{\circ}$ and $\phi=180^{\circ}$ at a height of $z=5 \mathrm{~m}$.

To estimate the wind pressure difference from the data, we return to the theoretical considerations from the first section. The airflow velocity has a square root dependence on the total pressure difference,

$$
v=r \sqrt{\left|\Delta p_{c}+\Delta p_{w}\right|}
$$

Velocity is the only measured quantity in this equation, so to extract $\Delta p_{w}$ we need an estimate for $r$ and $\Delta p_{c}$. The factor $r$, which depends primarily on the geometry of the airflow passages, can be extracted from the data when the wind pressure is minimal, so that $v=r \sqrt{\Delta p_{c}}\left(\right.$ Fig. 11; fitted only on calm days $\left.\left(v_{w}<2 \mathrm{~m} / \mathrm{s}\right)\right)$. Two resistance factors were determined separately for updraft $\left(r_{u p}\right)$ and downdraft $\left(r_{\text {down }}\right)$. The pressure difference of the chimney effect $\Delta p_{c}$ is obtained from Eq. 1, using $\Delta h=40 \mathrm{~m}$ and $T_{\text {in }}=9.2{ }^{\circ} \mathrm{C}$ (the temperature that gave the best fit in Figure 11 for Pisani Passage and the $T_{\text {out }}$ time series). We can now simply use Eq. 3. to calculate the remaining unknown pressure difference using the measured airflow velocity:

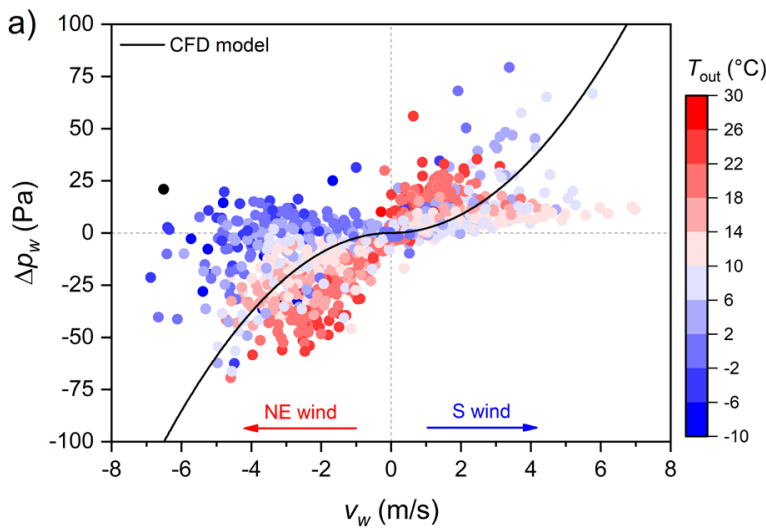

$$
\mp \Delta p_{w}=\left(\frac{v}{r}\right)^{2} \pm \Delta p_{c} .
$$

The sign of $\Delta p_{c}$ and the choice of the resistance factor, $r_{u p}$ or $r_{\text {down }}$, depends on the airflow direction, while the sign of $\Delta p_{w}$ depends on the wind direction ( $\mathrm{S}$ positive, NE negative). The results presented in Figure $14 \mathrm{a}$ show a very rough agreement between $\Delta p_{w}$ of the CFD model and the value estimated from the data. The scatter could be due to the uncertainties in the factor $r$ resulting from the fit with large scatter in the airflow velocity even for low outside winds (see Fig. 11). The origin of the scatter is beyond the scope of this work. To address it, airflow in a much more complex system than the one assumed here would have to be considered. To mitigate this scatter, we again use only the points where $T_{\text {in }} \approx T_{\text {out }}=9.2{ }^{\circ} \mathrm{C}$, the situation where we expect the wind-driven effect to be dominant (Fig. 14b). The quadratic curve fitted to these data (black points and black dashed line) roughly follows the CFD model curve (solid line) with larger differences for stronger $\mathrm{S}$ winds $(>4 \mathrm{~m} / \mathrm{s})$.

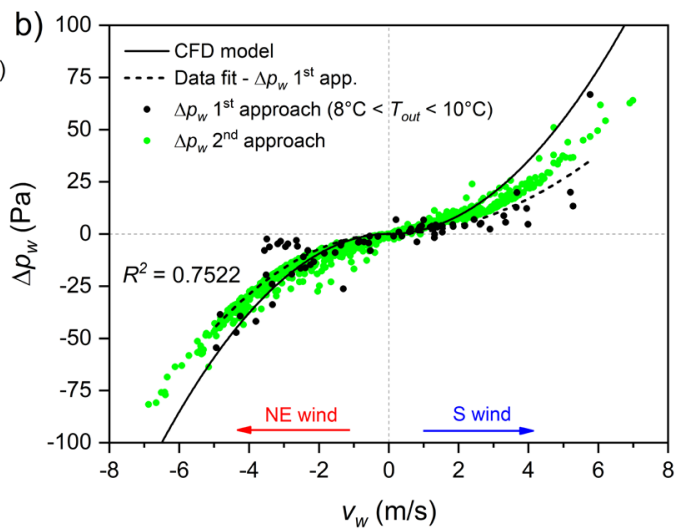

Fig. 14. Comparison of the wind pressure differences, $\Delta p_{w}$, obtained with the two approaches discussed in the text. In (a), the data points of the first approach are colored according to the outside temperature ranging from $-10^{\circ} \mathrm{C}$ to $30^{\circ} \mathrm{C}$ as daily values, and the points scatter around the model line with a predictable pattern due to the residual dependence on temperature. In (b), these points are filtered by the $8^{\circ} \mathrm{C}<T_{\text {out }}<10^{\circ} \mathrm{C}$ criterion (black points), fitted to a quadratic relationship (black dashed line; $R^{2}=0.7522$ ), and compared with the results of the second approach (green points). Both results follow the theoretical quadratic relationship determined by the CFD model (black curve).

Another way to estimate $\Delta p_{w}$ is to consider situations where the airflow in the passage stops or is close to zero. In this case the wind pressure is opposite to the chimney flow pressure, $\Delta p_{w}=-\Delta p_{c}$. Thus, taking, $\Delta p_{w}=c_{w} v_{w^{\prime}}^{2}$ and $\Delta p_{c}=c_{c} \Delta T$, where $c_{w}$ and $c_{c}$ are coefficients for the wind-driven and chimney effects, we obtain a square-root relationship between wind velocity and temperature difference, $v_{w}= \pm \sqrt{\frac{c_{c}}{c_{w}}} \sqrt{|\Delta t|}($ Fig. 15). The goodness of fit, $R^{2}=0.5761$, gives some justification to this approach. From Eq. 1. we obtain $c_{c}=\frac{\rho_{\text {out }} g \Delta h}{T}$. Here we have used an average air density, $\rho_{\text {out }} \stackrel{T_{\text {in }}}{=} 1.19 \mathrm{~kg} / \mathrm{m}^{3}$, $\Delta h=40 \mathrm{~m}$ and $T_{\text {in }}=9.2^{\circ} \mathrm{C}$, giving a $c_{c}$ value of $1.65 \mathrm{~K}^{-1}$. The coefficient $c_{w}$ is obtained from the fit between $v_{w}$ and $\sqrt{|\Delta T|}$, separately for the effect of $\mathrm{S}$ (positive) and $\mathrm{NE}$ wind (negative; Fig. 15). Finally, $\Delta p_{w}$ is calculated from $\Delta p_{w}=c_{w} v_{w}^{2}$ and compared with the first approach (Fig. 14b). Both approaches yielded similar estimates of $\Delta p_{w}$ and show good agreement with the CFD model.

Using the previous estimates, we can now calculate the relative contribution of wind pressure for $\mathrm{NE}$ and

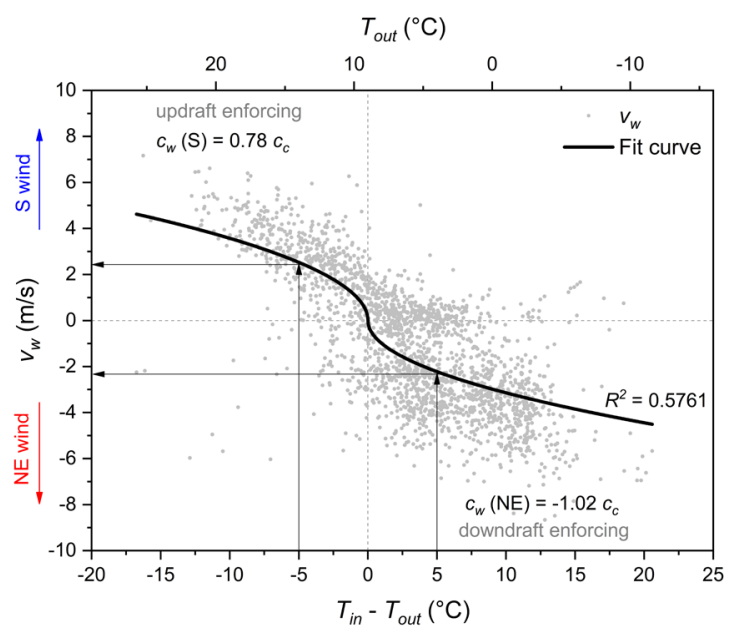

Fig. 15. Relationship between wind velocity and temperature difference under the condition when cave ventilation stops or is close to zero $|v|<0.1 \mathrm{~m} / \mathrm{s}$. The square-root relationship is indicated by the black curve. Several threshold values of this effect can be read (black arrows), which are explained in the text. 
$\mathrm{S}$ winds (Fig. 16). All observations with outside wind in the given interval $\left(-10^{\circ} \mathrm{C}<T_{\text {out }}<30^{\circ} \mathrm{C}\right)$ were used and $\Delta p_{c}$ and $\Delta p_{w}$ were calculated from Eq. 1 and Eq. 4. Point kriging with an interval of $0.4 \mathrm{~K}$ and $0.4 \mathrm{~m} / \mathrm{s}$ was used. As an example, the isoline with value 0.5 indicates all combinations of $T_{\text {out }}$ and $v_{w}$ where winddriven effect and chimney effect are equal.

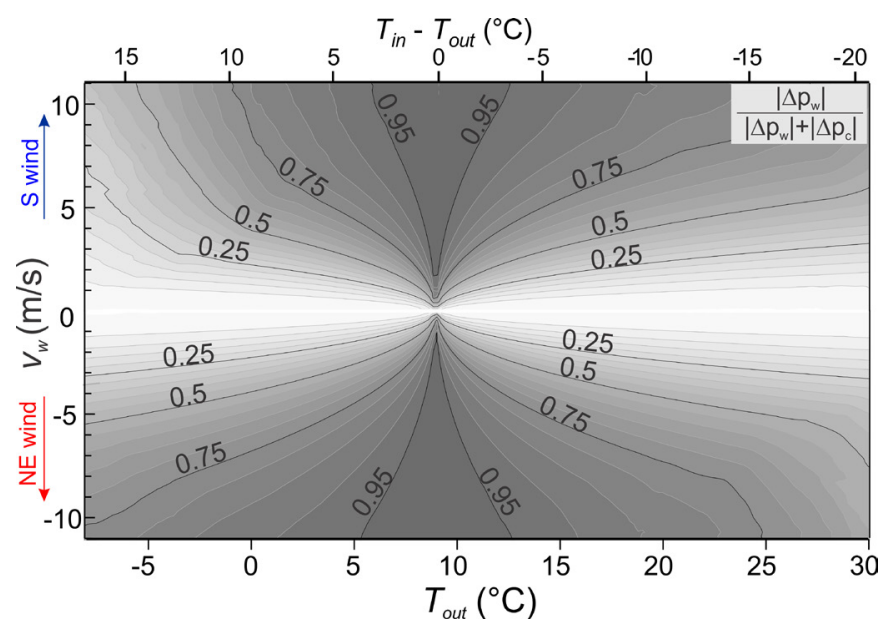

Fig. 16. Contour plot of the relative contribution of wind pressure to total driving pressure (from 0.25 to 0.95 in 0.05 intervals) for different outside temperatures and wind velocities. As expected, the contribution increases with wind velocity and decreases for positive or negative outside temperature extremes.

Figure 15 can also be used to find some useful thresholds for the wind-driven effect, regardless of pronounced scatter. Ideally, the relationship described by the black curve (with the conditions of the second approach to calculating $\Delta p_{w}$ ) gives an estimate of the minimum wind speed necessary to counteract the theoretical driving force of the chimney flow. For example, the black arrows show that a downdraft caused by the chimney flow at $\Delta T=-5^{\circ} \mathrm{C}$ could be stopped by as little as $2.5 \mathrm{~m} / \mathrm{s} \mathrm{S}$ wind, or that the updraft at $\Delta T=5^{\circ} \mathrm{C}$ could be stopped by $2.2 \mathrm{~m} / \mathrm{s} \mathrm{NE}$ wind. At $|\Delta T|=10^{\circ} \mathrm{C}$ this increases to $3.6 \mathrm{~m} / \mathrm{s}$ for the $\mathrm{S}$ wind, or $3.1 \mathrm{~m} / \mathrm{s}$ for the $\mathrm{NE}$ wind. Similar values are obtained from Figure 16 using the isoline 0.5. Such wind speeds are quite common in Postojna, as shown by the frequency distribution curves in Figure 17a, where about $60 \%$ of the time the wind will be higher than $2 \mathrm{~m} / \mathrm{s}$ and more than 20\% of the time higher than $4 \mathrm{~m} / \mathrm{s}$. In general, we can expect the wind-driven effect to be active throughout the year in Postojna Cave. As for the range of temperature differences, $|\Delta T|$ less than $5^{\circ} \mathrm{C}$ will occur $\sim 40 \%$ of the time and less than $10^{\circ} \mathrm{C} \sim 70 \%$ of the time (Fig. $17 \mathrm{~b}$ ).

In comparing the seasonal differences in the winddriven effect, the winter period is windier than the summer period (as shown in Fig. 7). The NE winds are strongest in January, February, and March, when one might expect the greatest interference of the typical winter updraft. An extreme example was February 2018, when the NE winds restricted ventilation for most of the month, leading to an unexpected increase in cave $p \mathrm{CO}_{2}$ (Kukuljan et al., 2021). On the other hand, S winds are weakest in July, August, and September, and therefore we can expect the least inference of typical summer downdraft. These could be the reasons for a rougher and more variable signal of the cave airflow for the winter period than for the summer (Fig. 5), and consequently for a larger scatter when comparing the airflow with $\Delta T$ in Fig. 11. Overall, the frequency distribution in Figs. 17a and $17 \mathrm{~b}$ also shows how NE winds are preferred over other directions and how updraft is less frequent than downdraft, again indicating a stronger wind-driven effect in cooler periods.
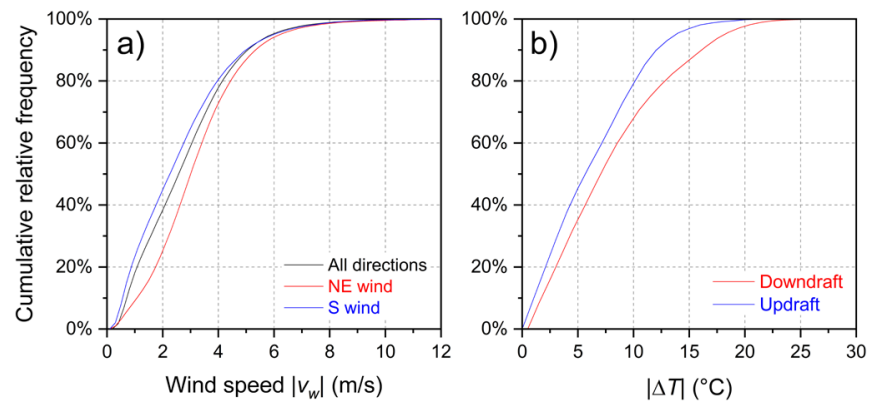

Fig. 17. Cumulative frequency distribution for wind speeds in Postojna (a) and temperature difference $\left(T_{\text {in }}-T_{\text {out }}\right)$ for Postojna Cave (b). Both NE winds and downdraft are favored over other wind/airflow direction, suggesting a larger wind-driven effect in winter than in summer.

\section{CONCLUSIONS}

Airflow in caves can be driven by different mechanisms. In this study, we show how near-surface pressure differences induced by outside winds interact with the chimney effect. The wind pressure between two cave entrances or air inlets or outlets depends on the relationship between the surface topography and the position of the air inlets or outlets, as well as the strength and direction of the wind. Outside winds can increase, decrease, or completely reverse airflow driven solely by the chimney effect. We used a CFD model to quantify the surface pressure field over the Postojna Cave system for winds of varying strength and direction. Despite the complexity of the cave system, the results show good agreement with pressure differences calculated from the data and from a simple empirical estimate of the chimney flow pressure. Wind pressure may become a dominant driving mechanism when cave systems have entrances at similar heights, such as in caves formed in karst plateaus. By affecting normal cave ventilation, winds can determine the dynamics and composition of air in the karst vadose zone and associated processes, including dissolution and precipitation of calcite. The analysis of outside winds should therefore be a necessary component of microclimatic studies in caves.

\section{ACKNOWLEDGMENTS}

The authors acknowledge the project "Methodology for monitoring the sustainable use of karst show caves with automatic measurements - role model - Postojna cave" (L6-9397), which was financially supported by the Slovenian Research Agency. The same agency supported the work of LK through the Young Researchers Programme. We thank Boštjan Grašič and Primož Mlakar for setting up and maintaining the cave 
monitoring infrastructure at Postojna Cave. We thank Matej Blatnik for drone images of the terrain above Postojna Cave. The drone was funded by the project "DEVELOPMENT OF RESEARCH INFRASTRUCTURE FOR THE INTERNATIONAL COMPETITIVENESS OF THE SLOVENIAN RRI SPACE - RI-SI-LifeWatch". The operation is co-financed by the Republic of Slovenia, Ministry of Education and Sport and the European Union from the European Regional Development Fund. Work by MDC during this study was supported by a Fulbright U.S. Scholar Award. Any opinions, findings, and conclusions or recommendations expressed in this material are those of the author(s) and do not necessarily reflect the views of the U.S. or Slovenian Governments.

Authorship statement: LK performed the data analyzes, produced most of the figures and, wrote the initial draft. FG initiated the study, designed the measurement network (with B. Grašič and P. Mlakar), analyzed and compiled the results of the CFD model. LK and FG interpreted the data. MDC added critical input and suggestions for additions and improvements, and proofread the manuscript. All authors read and approved the final version of the manuscript. We thank to Menzio GmbH for the work and support with the CFD modelling.

\section{REFERENCES}

Allard, F., Ghiaus, C., 2006. Natural ventilation in the urban environment. In: Santamouris M., Wouters, P. (Eds.), Building ventilation: The state of the art. Routledge, London, p. 1-37.

ARSO, 2021. Ministry of the environment and spatial planning, Slovenian Environmental Agency.

http://meteo.arso.gov.si/met/en/ [accessed May 6, 2021].

ARSO, 2020. Ministry of the environment and spatial planning, Slovenian Environmental Agency. http:/ / gis.arso.gov.si/evode/profile.aspx?id=atlas voda Lidar@Arso [accessed July 2, 2020].

Badino, G., 2010. Underground meteorology - "What's the weather underground?” Acta Carsologica, 39, 427-448. https://doi.org/10.3986/ac.v39i3.74

Badino, G., Chignola, R., 2019. Fluctuations of atmospheric pressure and the sound of underground karst systems: The Antro del Corchia Case (Apuane Alps, Italy). Frontiers in Earth Science, 7, 1-6. https://doi.org/10.3389/feart.2019.00147

Borsato, A., Frisia, S., Miorandi, R., 2015. Carbon dioxide concentration in temperate climate caves and parent soils over an altitudinal gradient and its influence on speleothem growth and fabrics. Earth Surface Processes and Landforms, 40, 1158-1170. https://doi.org/10.1002/esp.3706

Cigna, A., 1968. An analytical study of air circulation in caves. International Journal of Speleology, 3, 41-54. https://doi.org/10.5038/1827-806x.3.1.3

Conn, H.W., 1966. Barometric wind in Wind and Jewel caves, South Dakota. National Speleological Society Bulletin, 28, 55-69.

Covington, M.D., Perne, M., 2015. Consider a cylindrical cave: A physicist's view of cave and karst science. Acta Carsologica, 44, 363-380.

https://doi.org/10.3986/ac.v44i3.1925
Covington, M.D., 2016. The importance of advection for $\mathrm{CO}_{2}$ dynamics in the karst critical zone: An approach from dimensional analysis. In: Feinberg, J.M, Gao, Y., Alexander, E.C. (Eds.), Caves and karst across time, Geological Society of America Special Paper, 516, p. 113127. https://doi.org/10.1130/2015.2516(09)

Covington, M.D., Knierim, K.J., Young, H.A., Rodriguez, J., Gnoza, H.G., 2021. The impact of ventilation patterns on calcite dissolution rates within karst conduits. Journal of Hydrology, 593, 125824.

https://doi.org/10.1016/j.jhydrol.2020.125824

Fairchild, I.J., Baker, A., 2012. Speleothem science: From process to past environments. Wiley-Blackwell, Chichester, $421 \mathrm{p}$. https://doi.org/10.1002/9781444361094

Fernandez-Cortes, A., Sanchez-Moral, S., Cuezva, S., Cañaveras, J.C., Abella, R., 2009. Annual and transient signatures of gas exchange and transport in the Castañar de Ibor cave (Spain). International Journal of Speleology, 38(2), 153-162. https://doi.org/10.5038/1827-806X.38.2.6

Gabrovšek, F., Grašic, B., Božnar, M.Z., Mlakar, P., Udén, M., Davies, E., 2014. Karst show caves - How DTN technology as used in space assists automatic environmental monitoring and tourist protection Experiment in Postojna Cave. Natural Hazards and Earth System Sciences, 14, 443-457.

https://doi.org/10.5194/nhess-14-443-2014

Gregorič, A., Vaupotič, J., Gabrovšek, F., 2013. Reasons for large fluctuation of radon and $\mathrm{CO}_{2}$ levels in a deadend passage of a karst cave (Postojna Cave, Slovenia). Natural Hazards and Earth System Science, 13, 287 297. https://doi.org/10.5194/nhess-13-287-2013

Grisogono, B., Belušić, D., 2009. A review of recent advances in understanding the meso- and microscale properties of the severe Bora wind. Tellus, Series A: Dynamic Meteorology and Oceanography, $61 \mathrm{~A}, 1-16$. https://doi.org/10.1111/j.1600-0870.2008.00369.x

James, E.W., Banner, J.L., Hardt, B., 2015. A global model for cave ventilation and seasonal bias in speleothem paleoclimate records. Geochemistry, Geophysics, Geosystems, 16, 1044-1051. https://doi.org/10.1002/2014GC005658

Johnston, V., Martín-Pérez, A., Skok, S., Mulec, J., 2021. Microbially-mediated carbonate dissolution and precipitation; towards a protocol for ex-situ, cave-analogue cultivation experiments. International Journal of Speleology, 50(2), 137-155. https://doi.org/10.5038/1827-806x.50.2.2372

Kašing, M., Lenart, J., 2020. Cave airflow mechanism of a crevice-type cave: A case study from Czechia. International Journal of Speleology, 49(1), 55-67. https://doi.org/10.5038/1827-806X.49.1.2285

Kowalczk, A.J., Froelich, P.N., 2010. Cave air ventilation and $\mathrm{CO}_{2}$ outgassing by radon-222 modeling: How fast do caves breathe? Earth and Planetary Science Letters, 289, 209-219.

https://doi.org/10.1016/j.epsl.2009.11.010

Kozjek, K., Dolinar, M., Skok, G., 2017. Objective climate classification of Slovenia. International Journal of Climatology, 37, 848-860. https://doi.org/10.1002/joc. 5042

Kukuljan, L., Gabrovšek, F., Covington, M.D., Johnston, V.E., 2021. $\mathrm{CO}_{2}$ dynamics and heterogeneity in a cave atmosphere: Role of ventilation patterns and airflow pathways. Theoretical and Applied Climatology. https://doi.org/10.1007/s00704-021-03722-w

Lopes, A.M.G., 2003. WindStation - A software for the simulation of atmospheric flows over complex 
topography. Environmental Modelling and Software, 18, 81-96.

https://doi.org/10.1016/S1364-8152(02)00024-5

Luetscher, M., Lismonde, B., Jeannin, P.Y., 2008. Heat exchanges in the heterothermic zone of a karst system: Monlesi cave, Swiss Jura Mountains. Journal of Geophysical Research: Earth Surface, 113, 1-13. https://doi.org/10.1029/2007JF000892

Mattey, D.P., Atkinson, T.C., Hoffmann, D.L., Boyd, M., Ainsworth, M., Durrell, R., Latin, J.-P., 2021. External controls on $\mathrm{CO}_{2}$ in Gibraltar cave air and ground air: implications for interpretation of $\delta^{13} \mathrm{C}$ in speleothems. Science of The Total Environment, 146096. https://doi.org/10.1016/j.scitotenv.2021.146096

Milanolo, S., Gabrovšek, F., 2009. Analysis of carbon dioxide variations in the atmosphere of Srednja Bijambarska Cave, Bosnia and Herzegovina. BoundaryLayer Meteorology, 131, 479-493.

https://doi.org/10.1007/s10546-009-9375-5

Mlakar, P., Grašič, B., Božnar, M.Z., Popović, D., Gabrovšek, F., 2020. Information system for scientific study of the micrometeorology of karst caves - Case of Postojnska jama Cave, Slovenia. Acta Carsologica, 49, 297-310. https://doi.org/10.3986/ac.v49i2-3.7540

Nachson, U., Dragila, M., Weisbord, N., 2012. From atmospheric winds to fracture ventilation: Cause and effect. Journal of Geophysical Research, 117, G02016. https://doi.org/10.1029/2011JG001898

NOAA/ESRL, 2021. Global greenhouse gas reference network. Global monthly mean $\mathrm{CO}_{2}$. https://www.esrl.noaa.gov/gmd/ccgg/trends/global. html [accessed May 13, 2020].

Noronha, A.L., Hardt, B.F., Banner, J.L., Jenson, J.W., Partin, J.W., James, E.W., Lander, M.A., Bautista, K.K., 2017. Trade winds drive pronounced seasonality in carbonate chemistry in a tropical Western Pacific island cave-Implications for speleothem paleoclimatology. Geochemistry, Geophysics, Geosystems, 18, 384-399. https://doi.org/10.1002/2016GC006644

Pflitsch, A., Piasecki, J., Wiles, M., Horrocks, R., Ringeis, J., 2010. Dynamic climatologic processes of barometric cave systems using the example of Jewel Cave and Wind Cave in South Dakota, USA. Acta Carsologica, 39, 449-462. https://doi.org/10.3986/ac.v39i3.75

Prelovšek, M., Šebela, S., Turk, J., 2018. Carbon dioxide in Postojna Cave (Slovenia): spatial distribution, seasonal dynamics and evaluation of plausible sources and sinks. Environmental Earth Sciences, 77, 289. https://doi.org/10.1007/s12665-018-7459-6

Rakovec, J., Žagar, M., Bertalanic, R., Cedilnik, J., Gregoric, G., Skok, G., Žagar, N., 2009. Vetrovnost v Sloveniji [Wind conditions in Slovenia]. Založba ZRC, ZRC SAZU, 177p.

Riechelmann, S., Breitenbach, S.F.M., Schröder-Ritzrau, A., Mangini, A., Immenhauser, A., 2019. Ventilation and cave air $\mathrm{P}_{\mathrm{CO}_{2}}$ in the bunker-EMST cave system (NW Germany): Implications for speleothem proxy data. Journal of Cave and Karst Studies, 81, 98-112. https://doi.org/10.4311/2018ES0110

Šebela, S., 2019. Postojna-Planina cave system, Slovenia. In: White, W.B., Culver, D.C., Pipan, T. (Eds.), Encyclopedia of caves. Academic Press, London, p. 812-821. https://doi.org/https://doi.org/10.1016/B978-0-12814124-3.00098-4

Sebela, S., 2010. Accesses from the surface to the Postojna Cave system. Annales, Series Historia Naturalis, 20, 55-64.

Šebela, S., Turk, J., 2011. Local characteristics of Postojna Cave climate, air temperature, and pressure monitoring. Theoretical and Applied Climatology, 105, 371-386.

https://doi.org/10.1007/s00704-011-0397-9

Smith, A.C., Wynn, P.M., Barker, P.A., Leng, M.J., 2015. Drip water electrical conductivity as an indicator of cave ventilation at the event scale. Science of the Total Environment, 532, 517-527. https://doi.org/10.1016/j.scitotenv.2015.06.037

Smith, A.C., Wynn, P.M., Barker, P.A., Leng, M.J., Noble, S.R., Stott, A., 2016. Cave monitoring and the potential for palaeoclimate reconstruction from Cueva de Asiul, Cantabria (N. Spain). International Journal of Speleology, 45(1), 1-10. https://doi.org/10.5038/1827-806X.45.1.1928

Yang, T., Clements-Croome, D., 2012. Natural ventilation in built environment. In: Meyers, R.A. (Ed.), Encyclopedia of sustainability science and technology, Springer, New York, p. 6865-6896. https://doi.org/10.1007/978-1-4419-0851-3_488

Zheng, X., Shi, Z., Xuan, Z., Qian, H., 2018. Natural ventilation. In: Wang, R., Zhai, X. (Eds.), Handbook of energy systems in green buildings. Springer, Berlin, p. 1227-1270.

https://doi.org/10.1007/978-3-662-49120-1 8 